\section{OPEN ACCESS}

Edited by:

Frédéric Frappart,

UMR5566 Laboratoire d'études en géophysique et océanographie spatiales (LEGOS), France

Reviewed by:

Andrea Pain,

University of Maryland Center for Environmental Science (UMCES),

United States

David Brankovits,

Texas A\&M University at Galveston,

United States

Gwénaëlle Chaillou,

Université du Québec à Rimouski,

Canada

*Correspondence: Nils Moosdorf

nils.moosdorf@leibniz-zmt.de

Specialty section:

This article was submitted to Hydrosphere,

a section of the journal

Frontiers in Earth Science

Received: 31 August 2020

Accepted: 04 February 2021

Published: 14 May 2021

Citation:

MoosdorfN, Böttcher ME, Adyasari D,

Erkul E, Gilfedder BS, Greskowiak J, Jenner A-K, Kotwicki L, Massmann G,

Müller-Petke $M$, Oehler T, Post $V$,

Prien R, Scholten J, Siemon B,

Ehlert von Ahn CM, Walther $M$,

Waska $H$, Wunderlich $T$ and Mallast $U$

(2021) A State-Of-The-Art Perspective

on the Characterization of

Subterranean Estuaries at the

Regional Scale.

Front. Earth Sci. 9:601293.

doi: 10.3389/feart.2021.601293

\title{
A State-Of-The-Art Perspective on the Characterization of Subterranean Estuaries at the Regional Scale
}

\begin{abstract}
Nils Moosdorf ${ }^{1,2,3 *}$, Michael Ernst Böttcher ${ }^{4,5,6}$, Dini Adyasari ${ }^{1}$, Ercan Erkul ${ }^{2}$, Benjamin S. Gilfedder ${ }^{7}$, Janek Greskowiak ${ }^{8}$, Anna-Kathrina Jenner ${ }^{4}$, Lech Kotwicki ${ }^{9}$, Gudrun Massmann ${ }^{8}$, Mike Müller-Petke ${ }^{10}$, Till Oehler ${ }^{1}$, Vincent Post ${ }^{11}$, Ralf Prien ${ }^{12}$, Jan Scholten ${ }^{2}$, Bernhard Siemon ${ }^{11}$, Cátia Milene Ehlert von Ahn ${ }^{4}$, Marc Walther ${ }^{13}$, Hannelore Waska ${ }^{14}$, Tina Wunderlich ${ }^{2}$ and Ulf Mallast ${ }^{15}$
\end{abstract}

\begin{abstract}
${ }^{1}$ Department for Biogeochemistry / Geology, Leibniz Centre for Tropical Marine Research (ZMT), Bremen, Germany, ${ }^{2}$ Institute of Geosciences, University of Kiel, Kiel, Germany, ${ }^{3}$ Southern Cross Geoscience, Southern Cross University, Lismore, NSW, Australia, ${ }^{4}$ Geochemistry and Isotope Biogeochemistry, Leibniz Institute for Baltic Sea Research (IOW), Warnemünde, Germany, ${ }^{5}$ Marine Geochemistry, University of Greifswald, Greifswald, Germany, ${ }^{6}$ Department of Maritime Systems, Interdisciplinary Faculty, University of Rostock, Rostock, Germany, ${ }^{7}$ Department of Hydrology, Bayreuth Center of Ecology and Environmental Research (Bayceer), University of Bayreuth, Bayreuth, Germany, ${ }^{8}$ Institut für Biologie und Umweltwissenschaften, University of Oldenburg, Oldenburg, Germany, ${ }^{9}$ Institute of Oceanology, Polish Academy of Sciences, Sopot, Poland, ${ }^{10}$ Leibniz Institute for Applied Geophysics (LIAG), Hannover, Germany, ${ }^{11}$ Federal Institute for Geosciences and Natural Resources, Hanover, Germany, ${ }^{12}$ Marine Chemistry, Leibniz Institute for Baltic Sea Research (IOW), Warnemünde, Germany, ${ }^{13}$ Technische Universität Dresden, Faculty of Environmental Sciences, Department of Forest Sciences, Chair of Forest Biometrics and Forest Systems Analysis, 01062 Dresden, Germany, ${ }^{14}$ Institute for Chemistry and Biology of the Marine Environment (ICBM), University of Oldenburg, Oldenburg, Germany, ${ }^{15} \mathrm{Helmholtz}$ Centre for Environmental Research (UFZ), Leipzig, Germany
\end{abstract}

Subterranean estuaries the, subsurface mixing zones of terrestrial groundwater and seawater, substantially influence solute fluxes to the oceans. Solutes brought by groundwater from land and solutes brought from the sea can undergo biogeochemical reactions. These are often mediated by microbes and controlled by reactions with coastal sediments, and determine the composition of fluids discharging from STEs (i.e., submarine groundwater discharge), which may have consequences showing in coastal ecosystems. While at the local scale (meters), processes have been intensively studied, the impact of subterranean estuary processes on solute fluxes to the coastal ocean remains poorly constrained at the regional scale (kilometers). In the present communication, we review the processes that occur in STEs, focusing mainly on fluid flow and biogeochemical transformations of nitrogen, phosphorus, carbon, sulfur and trace metals. We highlight the spatio-temporal dynamics and measurable manifestations of those processes. The objective of this contribution is to provide a perspective on how tracer studies, geophysical methods, remote sensing and hydrogeological modeling could exploit such manifestations to estimate the regional-scale impact of processes in STEs on solute fluxes to the coastal ocean.

Keywords: subterranean estuary, submarine groundwater discharge, coastal aquifer, upscaling, biogeochemistry, geophysics, numerical modeling, ecology 


\section{INTRODUCTION}

Along global coastlines, meteoric groundwater discharges into the ocean (Church, 1996; Taniguchi et al., 2002; Zhou et al., 2019; Luijendijk et al., 2020). The subsurface zone where meteoric groundwater mixes with saltwater was termed the subterranean estuary (STE) by Moore (1999). This term was defined as "a coastal aquifer where groundwater derived from land drainage measurably dilutes saltwater that has invaded the aquifer through a free connection to the sea" (Moore, 1999). The relevance of STEs for matter cycling and coastal ecology is increasingly recognized by the scientific community (Rocha et al., 2021).

The term estuary originates from hydrology and is defined as the area where fresh river water and saline seawater mix (Prandle, 2009). Riverine estuaries are biogeochemical reactors that, amongst other processes, filter out about $20 \%$ of the dissolved silicon through reverse weathering (Tréguer and De La Rocha, 2013) or degas substantial amounts of riverine transported organic carbon as $\mathrm{CO}_{2}$ (Laruelle et al., 2010). By now, it is accepted that riverine solute fluxes to the coastal realm cannot be meaningfully quantified without considering transformations in the mixing zone of river estuaries (e.g., Kipp et al., 2020). For submarine groundwater discharge (SGD), the same should hold for subterranean estuaries (Robinson et al., 2018).

STEs are characterized by waters with geochemical signatures controlled by steep (physico-)chemical gradients of mixing terrestrial groundwater and seawater (Moore, 1999). The groundwater-seawater mixing zone embraces thematically different scientific fields, sometimes leading to confusion in terminologies. The term STE, for instance, is partly overlapping with the term 'coastal aquifers', which describes a groundwater system at the interface of land and sea in hydrogeology (Duque et al., 2020; Jiao and Post, 2019). Mixing of fresh and saline groundwater occurs differently in porous sedimentary aquifers than in karst or volcanic aquifers since the former have longer residence times and a higher reaction area between solid and fluid phase. STEs of the latter type are termed 'anchialine' (Bishop et al., 2015). Other studies use the term STE for karstic environments (e.g., Gonneea et al., 2014). In these situations, hydrology plays a major role in biogeochemical reactions (Brankovits et al., 2018), which is amplified by the karst's hydrogeological conditions. However, if karstic aquifers discharge in submarine springs with sufficient discharge rates, this can lead to freshwater mixing with seawater in the ocean itself in the form of plume-like structures (e.g., Fleury et al., 2007), whose nutrient fluxes can trigger algal blooms (Chen et al., 2020). Karst areas cover large parts of the global coastline (Goldscheider et al., 2020) and are essential groundwater-ocean interaction areas. Nevertheless, since processes in these conduit-systems differ sharply from those in porous sediments, we focus our assessment on STEs composed of porous sediments (Figure 1). Thus, we here use the term STE to describe the zone where fresh and saline groundwater mix in porous coastal aquifers in the subsurface, which is in line with the marine scientific literature (Robinson et al., 2018; Duque et al., 2020).
While STEs share the name estuary and the freshwatersaltwater mixing zone, they differ sharply from their riverine counterparts. The term "estuary" itself is questionable for STEs, since some definitions of estuaries also encompass the shape of the water body, e.g., as "semi-enclosed", basically referring to rivers (Wolanski, 2007). One crucial difference is residence time, which is in the order of days in riverine estuaries (Rasmussen and Josefson, 2002) and can be decades in STEs (e.g., Grünenbaum et al., 2020). The different residence time leads to different mixing processes: while in rivers, mixing can be in turbulent flow driven by wind, flow in STEs is generally linear and advection-dispersion driven. While in river estuaries, water-solid interaction is mostly limited to suspended or surface sediment as solid phase, STEs provide a wide range of minerals and solids to interact due to a lower water/rock ratio. In some STEs, anoxic conditions develop along subsurface flow-paths or be promoted by the inflow of $\mathrm{O}_{2}$ free groundwater, which changes the biogeochemical reactions compared to STEs where oxic conditions prevail (Slomp and Van Cappellen, 2004) or to oxic surface waters flowing through riverine estuaries. Thus, despite river estuaries and STEs sharing parts of their name, the processes involved can be very different. Also, while rivers can be treated as point sources of solutes and particulates to the coastal ocean, STEs can occur along long stretches of coast, and their geochemistry can vary substantially at the meter scale (e.g., Beck et al., 2016; Ehlert et al., 2016; Beck et al., 2017; Waska et al., 2019b) and even more at the regional scale.

In general, biogeochemical reactions alter the composition of terrestrial groundwater and saltwater that flow through STEs. Thus, the biogeochemical composition of the resulting SGD will not represent a conservative mixing between the fresh and saline waters entering the STE. In many STEs, the contribution of marine water circulating through the sediment ("marine SGD") to the total water fluxes exceeds that of terrestrial groundwater (e.g., Lopez et al., 2020). Groundwater of marine origin in the seafloor sediment and STEs will here be called "saline groundwater." Flow and transport in STEs are highly dynamic and locally variable. While discharge from unconfined shallow aquifers occurs near the shoreline, discharge from confined aquifers has been observed several kilometers offshore, depending on the hydrogeological conditions (Burnett et al., 2003; Gustafson et al., 2019). Mixing of fluids triggers biogeochemical reactions that can change the discharge composition compared to the original end-members (i.e., fresh groundwater and saltwater). Understanding the coupling between the physical and biogeochemical processes is the prerequisite to understand the role of STEs in controlling the geochemical composition of SGD (Robinson et al., 2018). Processes in STEs can substantially influence the water quality of the receiving water bodies and the biological processes in coastal waters (e.g., productivity, food web structure) and the full spectrum of the species inhabiting them, from bacteria (Adyasari et al., 2019a), algae, through grazers, detritivores, to invertebrates (Miller and Ullman, 2004), predatory fish (Pisternick et al., 2020), and birds (Kotwicki et al., 2014; Lecher and Mackey, 2018). The processes controlling the solute fluxes through STEs have been 


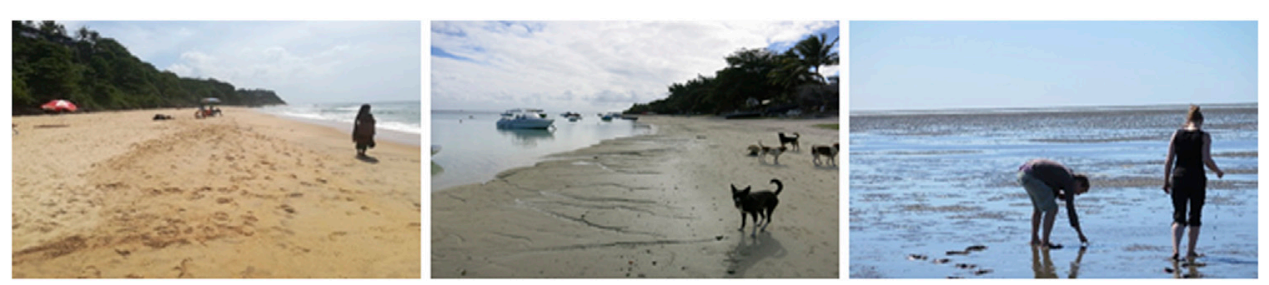

FIGURE 1 | Examples of beach settings in which active STEs developed. Left panel: Varkala Beach, India, where SGD seeps through the pore space below the waterline (Oehler et al., 2019b) (Photograph: T. Oehler). Middle panel: Trou aux Biches, Mauritius, where SGD is seeping out of the beach face during low tide (Photograph: J. Scholten). Right panel: SGD seeping along preferential flow-paths into the Wadden Sea near Cuxhaven, Germany (Photograph: Nils Moosdorf). Note that an STE often is not directly visible from the surface.

named among the main currently unsolved problems in hydrology (Blöschl et al., 2019).

Groundwater salinity distribution in STEs is typically characterized by a wedge of dense, saline groundwater that thins from the ocean inland underneath a fresh water body at the bottom of an aquifer (Figure 2). Along these water bodies' interface, the fresh and saline groundwater mix and a zone of intermediate salinities forms. Another saline recirculation cell, where saltwater infiltrates into the sediment, the so-called 'upper saline plume' (USP), can occur in settings with a sloping land surface where tides and waves run up along the beach (e.g., Lebbe, 1981; Robinson et al., 2007). Between the USP and the saltwater wedge, a 'freshwater discharge tube' evolves, focusing fresh SGD along the low water line under an active SGD seepage zone. These distinct water bodies have been described to shift, expand and contract as a consequence of seasonal groundwater recharge variations (Michael et al., 2005), spring-neap tidal cycles (Abarca et al., 2013; Heiss and Michael, 2014) or intensified wave conditions (Robinson et al., 2014). The shape of the STE is controlled by a large number of factors, such as geological heterogeneity (Geng et al., 2020), terrestrial groundwater discharge (Heiss and Michael, 2014), tidal amplitude (Abarca et al., 2013), sediment topography (Robinson et al., 2006; Waska et al., 2019b; Grünenbaum et al., 2020), or even seawater temperature (Kim et al., 2020).

STEs have been investigated from local, regional (Beck and Brumsack, 2012; Jurasinski et al., 2018) to global perspective (Beck et al., 2013; Rahman et al., 2019), and groundwater dynamics and driving forces have been reviewed (Santos et al., 2012; Robinson et al., 2018). For example, in Waquoit Bay, a comprehensive suite of STE studies related to biogeochemistry (Charette et al., 2005; Charette and Sholkovitz, 2006; Saenz et al., 2012; Gonneea et al., 2014), hydrology (Michael et al., 2005; Spiteri et al., 2008b), and tracer application (Dulaiova et al., 2008) has been conducted. The coastline of the Gulf of Mexico has provided a diverse geological background for local STE studies: from sandy beaches and lagoon systems in Florida (Santos et al., 2008; Roy et al., 2011; Pain et al., 2019), via an organic-rich STE in the eastern part of Mobile Bay, Alabama (Montiel et al., 2019), to developed karst system in Yucatan, Mexico (Gonneea et al., 2014; Brankovits et al., 2017; Brankovits et al., 2018). Biogeochemical STE studies in North America have also been conducted in the eastern (Hays and Ullman, 2007; O'Connor et al., 2018;
Tamborski et al., 2017) and western (Santoro et al., 2008; Boehm et al., 2014; Brown and Boehm, 2016) coastal areas of the contiguous United States, as well as boreal parts of Alaska (Lecher et al., 2016a) and Canada (Couturier et al., 2016; Sirois et al., 2018).

Many relevant field studies have been conducted outside North America. The development of an upper saline plume and the freshwater tube underneath was first demonstrated in Belgium by Lebbe (1981). He developed the conceptual model for the salinity distribution in unconfined aquifers influenced by tides based on field measurements and mathematical modeling. The Wadden Sea, located in the southern North Sea, is a wellstudied system where various geochemical (Beck et al., 2017; Linkhorst et al., 2017; Reckhardt et al., 2017; Rullkötter, 2009; Seidel et al., 2015; Waska et al., 2019b), hydrological (Moore et al., 2011; Seibert et al., 2019), as well as microbiological and biogeochemical (Musat et al., 2006; Al-Raei et al., 2009) studies have been conducted. Here, STEs have been shown to function as a coastal filter for material exchange and transformation. They are characterized by a high input of organic matter, intensive nutrient recycling, and organic matter remineralization rates (Billerbeck et al., 2006; Al-Raei et al., 2009). Other studied STEs in Europe are the Baltic Sea coast (Szymczycha et al., 2012; Donis et al., 2017; Jurasinski et al., 2018; Virtasalo et al., 2019) and the coast of France (Anschutz et al., 2009; Charbonnier et al., 2013; Oehler et al., 2017). In AsiaPacific, STE studies were conducted in South Korea (Kim et al., 2012; Lee et al., 2017) with particular attention paid to the volcanic Jeju Island (Kim et al., 2011; Kim et al., 2013), China (Liu et al., 2012; Wang et al., 2015; Yang et al., 2015; Jiang et al., 2020), Japan (Uchiyama et al., 2000; Nakada et al., 2011), Indonesia (Adyasari et al., 2019b), Cook Island (Erler et al., 2014), and Australia (Robinson et al., 2006; Robinson et al., 2007; Sanders et al., 2012).

The delivery of nutrients by terrestrial groundwater has been plentifully addressed also at continental to global scales (e.g., Beusen et al., 2013; Sawyer et al., 2016; Luijendijk et al., 2020), typically by multiplying the estimated water flux by the nutrient concentration of the fresh groundwater to obtain the nutrient mass flux. Such estimates do not consider the biogeochemical reactions in the STE that modulate the actual inputs to the coastal ocean. Local-scale studies have revealed the critical influence of biogeochemical reactions in the STE on land-ocean solute fluxes 


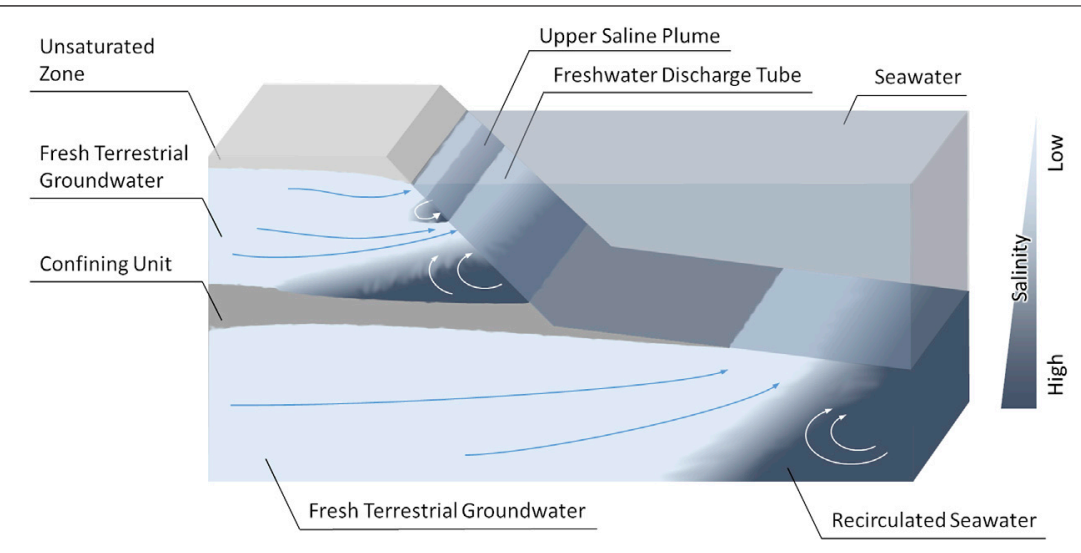

FIGURE 2 | Cross-section of a coastline highlighting the different parts of a subterranean estuary (STE).

and coastal ecology, even though STEs only cover a narrow stretch of the coast. This influence happens most certainly on a local and regional scale and is likely to have a significant effect on global scales. However, what remains unclear is how the knowledge and process descriptions at the local scale can be translated to the regional scale so that the impact of terrestrial SGD on the marine environment can be better quantified. We define the local scale as coastline lengths between $10^{0}-10^{2} \mathrm{~m}$ and the regional scale at $10^{3}-10^{5} \mathrm{~m}$. Here, we summarize local scale knowledge about processes in STEs and outline perspectives toward the representation and extrapolation of these processes at the regional scale.

\section{BIOGEOCHEMICAL CYCLING IN SUBTERRANEAN ESTUARIES}

Subterranean estuaries are biogeochemically active, characterized by microbially mediated element release, fixation and transformation reactions (Charette et al., 2005; Spiteri et al., 2008a; McGrath et al., 2012; Beck et al., 2017; Duque et al., 2020). Biogeochemical reactions within the STE and the export of reaction products into coastal waters can have wide-reaching consequences for ecologically detrimental coastal processes such as eutrophication and associated oxygen depletion of bottom waters (Slomp and Van Cappellen, 2004; Dybas, 2005), modification of ocean derived substances (e.g., detrital matter including POC and S species: Shum and Sundby, 1996), buffering or enhancing ocean acidification (Wang et al., 2014; Santos et al., 2015; Liu et al., 2017), and transport of contaminants from the land to the sea (Brovelli et al., 2007; Wang et al., 2012). Depending on redox conditions and water flux rates, this can be crucial in determining element speciation and balances in coastal waters with effects for phytoplankton productivity and potentially eutrophication (Taniguchi et al., 2019). Increased primary productivity can further intensify the transfer of nutrients and possible contaminants from lower to higher trophic levels.

Organic carbon forms a primary electron donor in the coastal subsurface, which interacts with various electron acceptors (e.g.,
$\mathrm{O}, \mathrm{N}, \mathrm{S}, \mathrm{Fe}$ and $\mathrm{Mn}$ species) derived from the sea or transported within the aquifer. Organic carbon stimulates a cascade of biogeochemical reactions relevant for local to global element turnover rates and budgets at the land-sea interface (Goodridge and Melack, 2014; Couturier et al., 2017; Cho et al., 2018; Seibert et al., 2019). Organic carbon quality, i.e., the fitness of organic molecules for microbial use as an electron donor (and sometimes acceptor), is dependent on its molecular composition, which is usually a complex mixture of terrestrial and marine-derived chemical moieties (Seidel et al., 2015).

The steep physicochemical gradients and enhanced microbial activity in STEs can also lead to mineralization processes of organic matter and hydrocarbons (Akam et al., 2020) as well as reoxidation reactions (Roy et al., 2013). These processes alter the redox conditions and the proton activity and may lead to the formation of authigenic solid phases, like carbonate, sulfide, sulfate or phosphate minerals (O'Connor et al., 2018; Riechelmann et al., 2020; Roy et al., 2013). Mineral formation may limit the concentrations of dissolved trace elements like metals being co-precipitated during iron sulfide formation (e.g., Huerta-Diaz and Morse, 1992). However, mineral formation also adds to the STE function as a filtering barrier between the terrestrial groundwater system and the sea for harmful chemical compounds. A well-known example of this is the socalled 'iron curtain,' an iron oxide rich zone that forms when oxic seawater is cycled through the beach sediments and mixes with anoxic or sub-oxic terrestrial groundwater (Chambers and Odum, 1990; Charette and Sholkovitz, 2002; Spiteri et al., 2006; Linkhorst et al., 2017; Sirois et al., 2018). The large sorption capacity of these iron oxides can be responsible for fixating aqueous pollutants, such as $\mathrm{P}$ and As species, before they become entwined in coastal food webs (Chambers and Odum, 1990; Bone et al., 2006; Beck et al., 2010).

Biogeochemically active areas can be unevenly distributed within the STE. This effect is amplified by the geological heterogeneity of flow regimes (Geng et al., 2020). Typically, certain conditions lead to the formation of biogeochemical 'hot-spots', areas of enhanced microbiological and chemical 
activity that drive the modification and transformation of ions and molecules in the subsurface (Santos et al., 2008). Microbial activity and community changes with salinity (Adyasari et al., 2019a). While the processes causing the observed spatial distribution of hot-spots are still poorly understood, an appropriate substrate (chemical and physical) is needed, as is an active flux of reactive electron acceptors and donors to maintain an energy flux for the microbial metabolism.

Thus, knowing the hydrogeology of a site (water origin, flow paths, residence times, mixing processes, and aquifer properties) is crucial for understanding the distribution of hot spots in STEs (Goodridge and Melack, 2014). Modeling suggested that densitydriven flow can enhance mixing in an STE when dense saline water from the upper saline plume or periodic flooding sinks into the underlying freshwater lens due to 'salt fingering' (Greskowiak, 2014). Other studies show the importance of heterogeneity of hydrogeological parameters in controlling an STE's shape (Weinstein et al., 2007) and the associated biogeochemical reactions (Heiss et al., 2020).

The temporal equivalent of 'hot-spot' is often termed 'hot moment'. The recognition that high element turnover (reactivity) areas are temporally dynamic is important (Liu et al., 2017; Waska et al., 2019b). Hot moments imply that enhanced biogeochemical activity areas are stationary neither in time nor location and will fluctuate depending on hydrological and chemical boundary conditions (Seidel et al., 2015). The incorporation of hot moments into the framework of biogeochemical activity in the subsurface has helped understand the previously ambiguous distributions of elements and molecules, e.g., in the framework of groundwater-river interaction (Vidon et al., 2010). At the coast, storms may, for instance, physically impact the freshwater input, the availability of substrates, or the seafloor morphology, which would change STE behavior. Due to storms, SGD rates can strongly change in a matter of days (Cho et al., 2021). More generally, hot moments in STE can be created through movements of the salinity gradient, when, e.g., phosphorus can desorb from aquifer sediment with increasing salinity and cause a spike of $P$ fluxes to the ocean that is not directly connected to terrestrial or marine inputs (Flower et al., 2017). Hot moments can also result from shifts in groundwater flow paths due to changed wave activity, which have been hypothesized to trigger pulses of arsenic transport into coastal waters due to instability of iron oxyhydroxides under changing redox conditions (Rakhimbekova et al., 2018). Water residence time is an essential factor influencing chemical reaction kinetics in the STE. For instance, in Waquoit Bay, longer residence times during winter caused attenuation of the groundwater nutrient load within the STE, whereas during periods of shorter residence time, SGD was nutrient-enriched (Gonneea and Charette, 2014).

The characterization of mineral authigenesis and its proxy potential in the STE requires sediment core material from the coastal and hinterland zone, best vertically resolved along transects through the STE to gain regional information. Whereas the physicochemical characterization of the aqueous solutions may allow for the identification of the current situation, the solid phases, when combined with appropriate age control, provide information about past SGD (Böttcher and Dietzel, 2010) as well as the movement of the geochemical mixing zone within the STE in response to sea-level change (Roy et al., 2010; Hong et al., 2018). The sea-level rise since the last glacial maximum caused a landward movement of STEs. Isotopic composition of authigenic minerals documents past changes in the land-sea hydrological conductivity and the evolution of the paleoenvironment.

In the following, the biogeochemical cycling of individual compounds in STEs will be discussed.

\section{Carbon}

Subterranean estuaries receive carbon (C) from both terrestrial and marine sources. Terrestrial dissolved inorganic carbon (DIC) is principally derived from biological processes taking place in the soil, and further influenced by biogeochemical processes in the groundwater (Bögli, 1980; Clark and Fritz, 1997; Deines et al., 1974). Terrestrial dissolved organic carbon (DOC) in STEs is either transported from the soil zone of the surrounding watersheds to the coast via groundwater or leached from vascular-plant material buried in coastal aquifers, such as paleosols (Sirois et al., 2018) or peat layers. Marine DOC is supplied to STEs by infiltrating seawater and produced locally in the STEs through remineralization of particulate organic matter (POM), for example, from coastal phytoplankton and macrobenthic beach wrack (Kim et al., 2019). DOC from both sources is transformed in STEs by microbial activity into $\mathrm{CO}_{2}$ and $\mathrm{CH}_{4}$.

Generally, terrestrial groundwater contributions will enhance the regional potential of coastal seawater to degas $\mathrm{CO}_{2}$ to the atmosphere and contribute to primary productivity. However, DIC from terrestrial groundwater may also induce intense carbonate mineral dissolution (if terrestrial groundwater is oversaturated in $\mathrm{CO}_{2}$ ) or lead to the precipitation of secondary carbonates (Deines et al., 1974; Wigley et al., 1978). The dissolution of carbonates in beach sands could be a substantial $\mathrm{pH}$-buffer preventing acidic groundwater from changing coastal marine environments. Mixing between different water masses may impact the saturation states of carbonate minerals in an aqueous solution (Bögli, 1980; Hanshaw and Back, 1979), which amplifies the STE effect on the carbon cycle. Carbonate dissolution in the groundwater-seawater mixing zone can form caves and caverneous structures (Mylroie and Carew, 1990). At the regional scale, the total amount of carbonate dissolution through saturation effects of mixing groundwater and seawater was estimated on the Yucatan Peninsula (Hanshaw and Back, 1980). Therefore, carbonate dissolution structures may potentially be used to derive information about STE activity at regional scales or trace back STEs over geological time scales. Precipitation or dissolution of authigenic carbonate minerals could develop characteristic $\mathrm{C}$ and $\mathrm{O}$ isotope as well as trace metal signatures that can be used to deduce the composition of past solute gradients in an STE (Böttcher and Dietzel, 2010).

SGD can also be a source of methane $\left(\mathrm{CH}_{4}\right)$ to coastal waters (Lecher et al., 2016b; O'Reilly et al., 2015), and $\mathrm{CH}_{4}$ gradients have been used to identify sites of SGD (e.g., Cable et al., 1996; Böttcher et al., 2021). In the Baltic Sea, seepage of terrestrial 
groundwater associated with $\mathrm{CH}_{4}$ releases was observed (Whiticar and Werner, 1981; Whiticar, 2002). STEs, both in karstic and porous settings, can be hotspots for $\mathrm{CH}_{4}$ oxidation that removes $\mathrm{CH}_{4}$ from groundwater before discharging into surface waters (Schutte et al., 2016; Brankovits and Pohlman, 2020). High variability in temporal (seasonal) and spatial (among geographically similar STEs) $\mathrm{CO}_{2}$ and $\mathrm{CH}_{4}$ concentrations and fluxes have been observed (Pain et al., 2019; Pain et al., 2020), complicating extrapolations to the regional scale.

Mineralization of DOM and $\mathrm{CH}_{4}$ in STEs changes ratios of total alkalinity (TA) over DIC depending on the involved electron acceptors and superimposing biogeochemical processes (Akam et al., 2020). The mineralization can result in characteristic carbon isotope signatures (Deines et al., 1974; Meister et al., 2019). Sheltered, organic-rich STEs with sulfate reduction as a dominant remineralization pathway may become enriched with DOC and TA (e.g., Sippo et al., 2016). The mineralization of organic carbon in STEs is often linked to several overlapping mechanisms, which can vary over seasonal cycles, such as the advective flow of terrestrial groundwater and saltwater and the availability of organic carbon (Kim and Kim, 2017; Liu et al., 2017; Kim et al., 2019). Marine-derived organic matter is assumed to be more abundant and more labile than terrestrially derived organic matter (Seidel et al., 2015) and is accompanied by an injection of oxygen, which accelerates mineralization rates. This "priming" by labile organic carbon and supply of oxygen may impact remineralization of groundwater-imported terrestrial DOC, but how and to which extent is weakly known. Since seawater circulation volumes exceed terrestrial groundwater throughputs in many STEs, marine DOC inputs could primarily determine the activity of the STE microbial reactor. Hence, most DOC released back into the coastal water column could be recycled/transformed. However, the relative contributions of terrestrial and marine organic carbon, as well as the function of the STE as a net source or net sink of organic carbon, are highly variable in space and time (Webb et al., 2019).

Carbon cycling in the STE on a local scale is best understood based on parallel profiling on land and at the seaside of the groundwater-seawater mixing zone since both terrestrial- and marine processes can control DIC and DOC fluxes. Besides direct tracking and benthic measurements of SGD leaving an STE (Donis et al., 2017), stable C isotope compositions of DIC, DOC and $\mathrm{CH}_{4}$ are useful variables in the characterization and even quantification of internal processes and modulations in STEs (e.g., Winde et al., 2014; Donis et al., 2017; Meister et al., 2019; Pain et al., 2019; Pain et al., 2020). Also, DOM molecular traits can elucidate organic carbon cycling in STEs (Seidel et al., 2015). At the regional scale, the C cycle is particularly complex to represent because of the considerable heterogeneity of unconfined aquifers and the formation of metabolically diverse 'hot spots'. Therefore, an abundance of information is necessary both from the land- and marine sides of the STE.

\section{Nitrogen}

Subterranean estuaries may act as either a source or sink of nitrogen $(\mathrm{N})$. Microorganisms catalyze different reactions of reactive $\mathrm{N}$, which include nitrate $\left(\mathrm{NO}_{3}^{-}\right)$, nitrite $\left(\mathrm{NO}_{2}^{-}\right)$, and ammonium $\left(\mathrm{NH}_{4}^{+}\right)$. The core nitrogen cycle involves four reductions $\left[\mathrm{N}\right.$ fixation $\left(\mathrm{N}_{2} \rightarrow \mathrm{NH}_{4}^{+}\right)$, denitrification $\left(\mathrm{NO}_{3}^{-} \rightarrow \mathrm{N}_{2}\right)$ ], assimilatory nitrate reduction $\left(\mathrm{NO}_{3}^{-} \rightarrow \mathrm{NH}_{4}^{+}\right)$, and dissimilatory nitrate reduction to ammonium (DNRA, $\mathrm{NO}_{3}^{-} \rightarrow \mathrm{NH}_{4}^{+}$) as well as two oxidation pathways [nitrification $\left(\mathrm{NH}_{4}^{+} \rightarrow \mathrm{NO}_{3}^{-}\right.$)] and anaerobic ammonium oxidation (anammox, $\mathrm{NH}_{4}^{+} \rightarrow \mathrm{N}_{2}$ ) (Kanehisa and Goto, 2000). The nitrogen cycle further includes organic nitrogen mineralization, or ammonification, which is the breakdown of organic $\mathrm{N}\left(\mathrm{N}_{\mathrm{org}}\right)$, leading to the release of $\mathrm{NH}_{4}^{+}$.

Nitrogen usually enters the system via $\mathrm{N}$ fixation (Fulweiler et al., 2007; Rao and Charette, 2012), organic input from terrestrial and marine sources, or terrestrial groundwater in the form of nitrate (Weinstein et al., 2011). STEs were classified as nutrient-contaminated STEs when they receive elevated amounts of nitrate from terrestrial groundwater and uncontaminated STEs when they produce nitrate internally from the mineralization of organic matter (Santos et al., 2009b; Loveless and Oldham, 2010; Robinson et al., 2018). In the latter case, tidal pumping provides $\mathrm{N}_{\text {org }}$ to the STE, which later is remineralized into $\mathrm{NH}_{4}^{+}$or nitrified to create $\mathrm{NO}_{2}^{-}$and $\mathrm{NO}_{3}^{-}$(Ullman et al., 2003; Santos et al., 2008; Charbonnier et al., 2013). The nitrifying microorganisms are aerobic chemoautotrophs; thus, nitrification generally occurs at the oxic surface layer of STEs where the ammonification rate is high, and $\mathrm{N}_{\text {org }}$ input and oxygen concentration are abundant (Santoro et al., 2008).

It has been shown that nitrate may be removed in permeable intertidal sediments from circulating seawater (Marchant et al., 2016), in some locations by up to 70\% (Wong et al., 2020). Permanent biological removal of reactive $\mathrm{N}\left(\mathrm{NO}_{3}^{-}\right.$and $\left.\mathrm{NH}_{4}^{+}\right)$ from the STE may be achieved through biological assimilation, denitrification and anammox, provided that contact time between the aqueous and solid phase of an STE is sufficient. Denitrification is reportedly the primary biogeochemical process responsible for $\mathrm{N}$ loss in coastal and marine systems (Canfield et al., 2010) and performed by a wide range of bacteria and archaea, mostly heterotrophic microorganisms. Particulate organic carbon (POC) in the coastal aquifer was reported as a major control on denitrification in STE (Kim et al., 2020). Under conditions where $\mathrm{NO}_{3}^{-}$inputs exceed the availability of carbon substrate for denitrification, DNRA may occur (Tiedje, 1988; Gardner et al., 2006), which, however, preserves $\mathrm{N}$ in the system as $\mathrm{NH}_{4}^{+}$. Anammox, another process of biological $\mathrm{N}$ removal (Jetten et al., 1998), may occur in an anaerobic, $\mathrm{NH}_{4}^{+}$-abundant, low organic matter environment (Sáenz et al., 2012). The cooccurrences of $\mathrm{N}$ transformation processes, such as simultaneous nitrification-denitrification, has been found in the STE due to the oxygen and organic matter stratification (Hays and Ullman, 2007; Erler et al., 2014) or rapid mixing of different water masses, creating both oxic and anoxic microzones (Uchiyama et al., 2000; Kroeger and Charette, 2008).

The $\mathrm{N}$ transformation processes are controlled mainly by groundwater residence time (Santos et al., 2008; Gonneea and Charette, 2014), redox condition (Slomp and Van Cappellen, 2004), availability of electron donors (Santoro, 2010), and mixing 
rate of freshwater and saltwater (Kroeger and Charette, 2008). They have been detected and measured by geochemistry or molecular biology approaches. Stable isotopes $\left(\delta^{15} \mathrm{~N}\right)$ and concentrations of reactive $\mathrm{N}$ help understand $\mathrm{N}$ behavior in STEs (Kroeger and Charette, 2008) and can also be manipulated as a tracer (Erler et al., 2014). Denitrification rates can also be calculated from STE sediment cores (DeSimone and Howes, 1996; Nowicki et al., 1999). Microbial $\mathrm{N}$ transformation can be determined by molecular detection, which involves extracting the microbial DNA from water or sediment samples (Santoro et al., 2006; Rogers and Casciotti, 2010; Hong et al., 2018; Adyasari et al., 2020).

Reactions in the nitrogen cycle in STEs are controlled primarily by microbiology. While at the local scale geochemistry or molecular biology assessment methods exist, regional scale tracers for these processes have yet to be identified. They could be indirectly inferred from STE physical properties (e.g., organic matter content and quality in host sediment, residence time, redox conditions) that control reaction rates and types. One example is the use of hyperspectral imaging to identify phytoplankton and CDOM concentration or total suspended solids (e.g., Brando and Dekker, 2003) and benthic information (e.g., Vahtmäe et al., 2020) in coastal waters if the signal is strong and clear enough given possible depth and turbidity. Lastly, if substantial quantities of gaseous $\mathrm{N}_{2}$ are produced by denitrification, it could be detected by geophysical methods under favorable conditions.

\section{Phosphorus}

Phosphorous (P) inputs into terrestrial groundwater are mainly derived from fertilizers, waste and sewage (Slomp and Van Cappellen, 2004), to a minor extent from the mineralization of organic matter (Froelich et al., 1979) or released from minerals as geogenic sources (Kazmierczak et al., 2020; Tao et al., 2020). Geogenic P sources are mostly of local importance and depend on the aquifer mineralogy. In saline groundwater, $\mathrm{P}$ is usually derived from the mineralization of organic matter (Froelich et al., 1979). In karstic STEs, where groundwater can reach surface waters via rapid conduit flow pulse, inputs of $\mathrm{P}$ are associated with high-intensity rainfall events. In such a system in southern Java (Indonesia), elevated P concentrations were linked to events with high groundwater discharge rates, leading to exceptionally high $\mathrm{P}$ inputs into coastal waters (Oehler et al., 2018).

Dissolved $\mathrm{P}$ has a high affinity to adsorb at mineral surfaces of carbonates (Gaudette and Lyons, 1980; Burton and Walter, 1990) and iron oxyhydroxides (Einsele, 1936; van der Grift et al., 2014). These minerals can precipitate in STEs, which thereby would reduce the amount of $\mathrm{P}$ that is transported via SGD (Pain et al., 2020). In Waquoit Bay, $P$ concentrations are 5-7 times higher in iron oxide rich sands than in the overlying surface sands, indicating how effectively processes in STEs can bind $\mathrm{P}$ (Charette and Sholkovitz, 2002).

Phosphorus concentrations along the salinity gradient of STEs usually behave non-conservatively. Elevated $\mathrm{P}$ concentrations are often associated with elevated groundwater salinity (Gaudette and Lyons, 1980), e.g., due to desorption from particles
(Suzumura et al., 2000), Fe reduction associated with organic matter mineralization, direct P liberation (Froelich et al., 1979), or the release of colloid-bound nutrients (Prouty et al., 2017a). Sporadic $\mathrm{P}$ release can also follow occasional saltwater intrusions. Thus, to understand the temporal P transport behavior in an STE, the mobility of the groundwater-seawater mixing zone needs to be known. Depending on the distance to the sediment surface and the SGD flow regime, particulate and dissolved $\mathrm{P}$ may be transported to coastal waters (e.g., Lipka et al., 2018). Therefore, the mobility and final release of $\mathrm{P}$ to surface waters indirectly depend on redox conditions and the specific composition of the aquifer (Gaudette and Lyons, 1980; Lewandowski et al., 2015).

Phosphorous cycling in the STE is on a local scale best investigated based on the analysis of pore waters and sediments along transects across the terrestrial groundwater end-member through the mixing zone. Porewater analyses should be combined with continuous monitoring of the composition in the pelagic system and complemented by element budgeting. Care has to be taken in separating $\mathrm{P}$ in porewater derived from the groundwater against that derived from processes within an STE (Suzumura et al., 2000; Price et al., 2010; Prouty et al., 2017b). Redox conditions in the terrestrial groundwater, as well as the abundance of iron oxyhydroxides and carbonate minerals in the STE sediment need to be known or approximated to estimate the regional scale effect of STEs on $\mathrm{P}$ transport and release to the coastal ecosystem.

\section{Sulfur}

Subterranean estuaries gain most sulfur (S) from seawater, of which sulfate $\left(\mathrm{SO}_{4}^{2-}\right)$ is a major constituent. In brackish-marine sediments, microbial dissimilatory $\mathrm{SO}_{4}^{2-}$ reduction is the primary anaerobic process responsible for the mineralization of organic matter (Jørgensen, 1982), leading to the formation of dissolved sulfide. Sulfate reduction is also responsible for the oxidative conversion of methane into dissolved carbon dioxide (Boetius et al., 2000). Nevertheless, STEs also receive S from terrestrial groundwater, where dissolved $\mathrm{SO}_{4}^{2-}$ may originate from the dissolution of aquifer minerals like gypsum or oxidation of iron sulfides, like pyrite (Zhang et al., 2012). In young water bodies, anthropogenic sources, like acid rain, acid mine drainage and fertilizers, may further enhance $\mathrm{SO}_{4}^{2-}$ loads (Clark and Fritz, 1997; Alorda-Kleinglass et al., 2019).

In STEs containing sufficient electron donors, $\mathrm{SO}_{4}^{2-}$ reduction might be enhanced and can outcompete methanogenesis (Slomp and Van Cappellen, 2004). These systems can differ substantially in their biogeochemical processes and thereby in their release of climate-relevant gas emissions (Böttcher et al., 2021). Hydrogen sulfide may furthermore be re-oxidized by solid and aqueous species or be precipitated as iron sulfides (Luther et al., 1991; Rickard, 1997), thus acting as a sink for other dissolved metals (Huerta-Diaz and Morse, 1992). Overall, the dissolved $\mathrm{SO}_{4}^{2-}$ availability controls the biogeochemical element cycling in the groundwater-seawater mixing zone and specifically the coupled sulfur-carbon-metal cycle. In particular, the coupled stable sulfur and oxygen isotope composition of dissolved $\mathrm{SO}_{4}^{2-}$ in the STE pore waters provides information about sources, sinks and 
cycling of sulfur (Fritz et al., 1989; Zhang et al., 2012) that may even be traced in an impacted shallow water column. Using sulfur isotopes as a tracer will be difficult at the regional scale due to the many involved controls and high sampling effort necessary.

\section{Metals}

Dissolved metal concentrations in pore waters of STEs (e.g., Ba, $\mathrm{Cd}, \mathrm{Cu}, \mathrm{Fe}, \mathrm{Mn}, \mathrm{Mo}, \mathrm{Pb}, \mathrm{Zn}$ ) depend strongly on the mineralogy of the aquifer and may be enriched by anthropogenic contamination (Bone et al., 2007; Knee and Paytan, 2011). Many of the trace metals have particular ecological relevance as (micro)nutrients or toxins (Salt et al., 1995; Beck et al., 2010), and their signatures may be recognizable in near-shore STE sediments (Knee and Paytan, 2011). Submarine groundwater discharge is relevant for marine alkaline earth metal composition (Mayfield et al., 2021), a significant source of rare earth elements to the ocean and could be the missing link in the global distribution of Neodynium (Nd), a key proxy for oceanic water-mass mixing (Johannesson and Burdige, 2007; Chevis et al., 2015; Paffrath et al., 2020). Formation of complexes and colloids, sorption on the surface of particles, ion exchange, and changes in speciation are some of the relevant processes that control metal mobility, reactivity and toxicity (Charette and Sholkovitz, 2006; Waska et al., 2019a). The interactions between solutes and aquifer particles exert a firm control on trace metal transport in STEs and are strongly influenced by redox and $\mathrm{pH}$ conditions, salinity, and ligand availability (Knee and Paytan, 2011).

One of the quantitatively most abundant metals in STEs is iron $(\mathrm{Fe})$. Its mobility is highly sensitive to changes in redox milieu and pH (Spiteri et al., 2006). Upon precipitation, iron-oxyhydroxides $(\mathrm{FeOOH})$ and iron sulfides (FeS) provide a substrate for sorption and incorporation of metals, $\mathrm{Si}, \mathrm{As}, \mathrm{DOM}$, and especially $\mathrm{P}$ (Huerta-Diaz and Morse, 1992; van der Grift et al., 2014). Furthermore, a substantial impact of $\mathrm{FeOOH}$ precipitation on the fractionation of different DOM fractions was described (Linkhorst et al., 2017). Iron mineral formation in the STE may remove selected trace metals from the aqueous solution (Charette and Sholkovitz, 2002; Charette and Sholkovitz, 2006; Böttcher and Dietzel, 2010) and release them later, when the reactive front may have shifted. Karst systems, in particular, can be efficient pathways for the exfiltration of metal-enriched waters through an STE into the coastal zone due to short aquifer residence times, enhanced flow rates, and a low mineral surfaces to groundwater volume ratio (Knee and Paytan, 2011; Pain et al., 2020).

The use of trace metals to identify SGD in the coastal waters depends on their reactivity in redox and $\mathrm{pH}$ gradients. $\mathrm{Mn}$, for instance, remains mobile for some time even under oxic conditions (Kowalski et al., 2012; Winde et al., 2014), whereas Fe is efficiently fixed in the STE. This stability difference leads to fractionation of these metals (Balzer, 1982) and the trace metals that sorb on them. On a regional scale, selected trace metals like $\mathrm{Mn}$ or $\mathrm{Ba}$ in the water column may help to detect and even quantify SGD in tidal areas (Kowalski et al., 2012; Winde et al., 2014).

\section{APPROACHES TO ASSESSING STE PROCESSES AT THE REGIONAL SCALE}

\section{Geochemical Tracers}

Geochemical tracers can help to identify locations of STEs as well as processes within them. In general, tracers are characterized by distinct differences in concentrations or isotopic compositions between groundwater and seawater. Salinity or conductivity is a ubiquitous tracer since freshening of coastal ocean waters without a nearby surficial terrestrial source is an indicator of STE influence. However, traces of freshening diminish quickly due to mixing with seawater, and interpretations can be ambiguous due to other potential freshwater sources, such as rain.

Thus, other geochemical tracers with higher sensitivity, i.e., large concentration differences between groundwater and seawater, are applied. These are e.g. the natural radionuclides of radon $\left({ }^{222} \mathrm{Rn} ; \mathrm{t}_{1 / 2}=3.8\right.$ days; $\mathrm{Rn}$ in following $)$ and radium $\left({ }^{224} \mathrm{Ra}\right.$; $\mathrm{t}_{1 / 2}=3.7$ days; ${ }^{223} \mathrm{Ra} ; \mathrm{t}_{1 / 2}=11.4$ days; ${ }^{228} \mathrm{Ra} ; \mathrm{t}_{1 / 2}=5.75$ years; ${ }^{226} \mathrm{Ra} ; \mathrm{t}_{1 / 2}=1,600$ years, $\mathrm{Ra}$ in the following), which are generally enriched in STE groundwater compared to surface waters. They can provide qualitative and quantitative information on sources and types of water sources to the STE, estimates of seawater residence times in the STE, as well as an overall quantification of the water flux out of the STE (i.e., SGD) into the coastal sea and open ocean (Taniguchi et al., 2019), while the results often include large uncertainties (Rodellas et al., 2021).

In addition to imports by sea- and groundwater, a fraction of the Ra and Rn in STEs pore waters is produced locally in sediment mineral grains by the decay of the radioactive parents Thorium (Th) and ${ }^{226} \mathrm{Ra}$, respectively. In pore waters with low chloride content Ra is typically immobilized by sorption to clay and $\mathrm{Fe}$ and Mn oxide surfaces whereas, at salinities $>\sim 3$ practical salinity units (PSU), it behaves conservatively and can be used to trace water flow paths and fluxes (Webster et al., 1994). As an inert noble gas, $\mathrm{Rn}$ is not affected by the chemical composition of pore waters and geochemical reactions within the STE. The Ra and Rn pore water concentration will depend on the thorium/radium content of aquifer sediments, the recoiled efficiency, the residence time (i.e., the time elapsed since the water entered the STE) as well as $\mathrm{Mn}$ and $\mathrm{Fe}$ redox cycling. As seawater $\mathrm{Ra}$ and $\mathrm{Rn}$ concentrations usually are low, enrichment of these isotopes in coastal waters can be used to locate water fluxes out of the STE and quantify them in a mass balance approach assuming a known groundwater endmember (e.g., Garcia-Solsona et al., 2008).

A sampling of radionuclides can be done by boat at regional scales (Moore, 2000; Schubert et al., 2019; Stieglitz et al., 2010) (Figure 3). Time series measurements provide information on the temporal component of Ra and Rn fluxes and thus can be used to understand the dynamics of SGD in response to changing boundary conditions such as tides or storm events (Burnett and Dulaiova, 2003; Santos et al., 2009a). However, identifying STEs and associated terrestrial groundwater flux remains very challenging due to overlapping groundwater circulation processes and pathways, which are difficult to differentiate based on Rn and Ra only. 


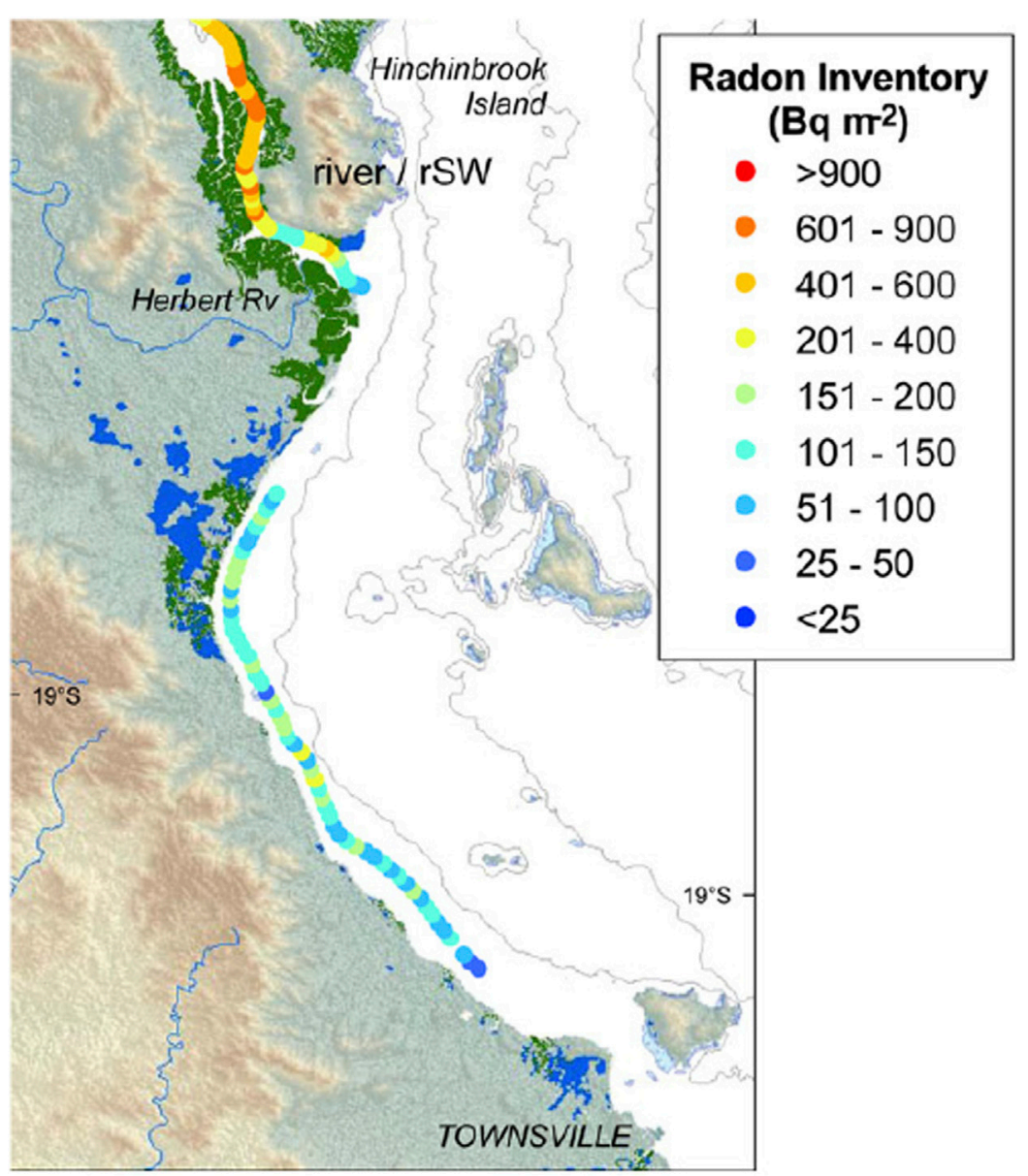

FIGURE 3 | Example of a regional scale Rn survey in Queensland, Australia (Stieglitz et al., 2010). Permission for reprint was provided by the copyright-holder.

The quantification of SGD using Rn and $\mathrm{Ra}$ is based on solving a mass balance of these radionuclides, considering all their major sources and sinks. It is usually done on sub-regional scales of up to 100s of meters, with notable exceptions for the Atlantic Ocean (Moore et al., 2008), the Mediterranean Sea (Rodellas et al., 2015) and the global oceans (Kwon et al., 2014). The quantification can be done either assuming a steady-state or using a non-steadystate approach when influxes from the STE are transient (Burnett et al., 2003; Moore, 2003; Hwang et al., 2005; Burnett et al., 2006). The steady-state assumption needs to be critically appraised when analyzing field data used in the mass-balance calculation, especially when using Rn. Turbulent conditions caused by wind and wave action can lead to excessive degassing before and during field campaigns so that the assumption of steady state between source and loss terms is not met. Indeed, it can be difficult to measure any $\mathrm{Rn}$ in surface waters following rough conditions. The 'memory' effect of variable degassing for the $\mathrm{Rn}$ balance tends to be around 5 days, but depends on factors such as water depth. In general, a non-steady state mass-balance together with continuous $\mathrm{Rn}$ measurements is better suited to dynamic conditions in the coastal zone (e.g., Santos et al., 2009c; Gilfedder et al., 2015).
The concentrations of tracers in SGD, i.e., the end-member concentrations of $\mathrm{Ra}$ and $\mathrm{Rn}$, must be known to translate a mass flux into a water flux. Constraining these end-member concentrations is one of the most critical and uncertain steps of mass balance approaches. Groundwater concentrations may have substantial temporal and spatial variations caused by the heterogeneity of parent isotopes, different groundwater circulation pathways, hydrological and marine forcing, changes of geochemical processes within the STE as well as variability in terrestrial sources (Gonneea et al., 2013; Cho and Kim, 2016; Rocha et al., 2016; Cerda-Domenech et al., 2017). To overcome this problem, averaging a large number of end-member concentration measurements or taking the maximum and minimum end-member concentration to provide an envelope of possible SGD flux rates are common approaches (Moore, 1996; Beck et al., 2007). Nevertheless, the variability in the end-member concentrations remains the primary challenge for reliable quantification of SGD since shortcomings in accounting for the heterogeneity of end-members at local- and regional scales remain unsolved.

On a local scale, seepage meter measurements, as well as water balances, allow independent verifications of radionuclide-based 
SGD rates (Povinec et al., 2012). However, on regional scales, verifications are still lacking or show systematic differences between tracer and model approaches (Prieto and Destouni, 2011). Nevertheless, $\mathrm{Ra}$ and $\mathrm{Rn}$ isotopes can be applied to map spatial and temporal changes in SGD, which under certain conditions would be a first indicator for the potential presence of an STE. $\mathrm{Ra}$ and $\mathrm{Rn}$ isotopes were used in regional scale SGD estimates.

Another isotopic tracer that can be applied for STE studies is the stable isotope composition of water $\left({ }^{2} \mathrm{H} /{ }^{1} \mathrm{H},{ }^{18} \mathrm{O} /{ }^{16} \mathrm{O}\right.$, here shortly called "water isotopes"), which is a well-established tracer in hydro (geo)logical studies for the quantification of mixing processes and the deduction of water mass sources. Terrestrial groundwater is substantially more depleted in the heavier isotopes than seawater (Gat, 1996; Hoefs, 2018) and contains further information about the integrated meteorological conditions in the recharge area. Therefore, water isotopes are widely used in studies of SGD or STE (e.g., Burnett et al., 2006; Povinec et al., 2011; Rocha et al., 2016; Oehler et al., 2017; Duque et al., 2019). Time series can reveal the variability of terrestrial groundwater inputs on different time scales, particularly in dynamic karst STEs. Although still in its infancy, the extension of stable isotope characterization toward a triple isotope approach considering ${ }^{17} \mathrm{O}$ (resp. ${ }^{17} \mathrm{O}$ excess Sharp et al., 2018) may allow freshwater sourcing on the scale of regional STEs. Minerals formed in the mixing zone may record the parent solution's isotopic signature, providing opportunities for studies of past STE conditions.

Besides the stable isotopes of water, groundwater formed after the early 1960s may contain tritium $\left({ }^{3} \mathrm{H}\right)$, which has been used for dating purposes (Begemann and Libby, 1957; Bethke and Johnson, 2008). Meanwhile, the anthropogenic component, the atmospheric contamination of the water cycle by surface nuclear tests, has reached a natural background level. However, combined with its daughter isotope ${ }^{3} \mathrm{He}$ and $\mathrm{Ne}$ (Tolstikhin and Kamenskii, 1969; Sültenfuss et al., 2009), tritium still can be used for regional age estimation of the freshwater component in STEs (Röper et al., 2012; Post et al., 2019; Grünenbaum et al., 2020). The accumulation of ${ }^{4} \mathrm{He}$ is furthermore used in older groundwater dating (Bethke and Johnson, 2008). Other noble gas isotopes useful in the hydrogeology of STEs are ${ }^{39} \mathrm{Ar}$ and ${ }^{85} \mathrm{Kr}$ (e.g., Sánchez-Úbeda et al., 2018).

Local-scale geochemical investigation of STEs ideally includes vertical transects through the STE, a detailed physicochemical analysis, and solid-phase profiles from core material for a further microanalysis to identify precipitated authigenic solid phases. Measuring transects along the beach face enables mapping the spatial distribution of the biogeochemical environment, reactions and residence times over distances from tens to hundreds of meters. Larger scale mapping is challenging due to laborintensive field sampling and increasing heterogeneity of the subsurface at larger scales meaning that extrapolation between transects is difficult.

Different circulation pathways in the STE can also be examined by exploiting the different half-lives of Ra isotopes, ranging from tidal to seasonal time scales. Assuming a steadystate hydrological situation, residence times can be estimated applying a general advective transport model in which the concentration of $\mathrm{Ra}$ and $\mathrm{Rn}$ in pore waters is a function of the supply of the radionuclides and their loss by decay and advection (Bokuniewicz et al., 2015; Tamborski et al., 2017). One of the main uncertainties in this approach is the lithological composition (mineral content, grain size, porosity) of the STE, which is assumed to be homogenous in space and in time throughout the STE. In reality, however, the heterogeneity in the STE causes a wide range of radionuclide supply rates (Beck and Cochran, 2013). Furthermore, temporally and spatially variable geochemical cycling of $\mathrm{Fe}$ and $\mathrm{Mn}$ and associated oxides profoundly influence the $\mathrm{Ra}$ pore water release (Gonneea et al., 2008). Since $\mathrm{Ra}$ is conservative in saline waters only, Ra-based residence times are only meaningful when seawater dominates the circulation through the STE. In contrast, $\mathrm{Rn}$ can be applied in both the fresh and brackish parts of the STE but is sensitive to ${ }^{226} \mathrm{Ra}$ distributions in the sediments as the parent isotope. Short term hydrological forcing like tides, wave set-up and induced circulation may also cause non-steadystate situations resulting in biases in residence times estimates. Finally, mixing of waters with different ages can lead to errors in the residence time estimates (which is similar to the real mean age of a water parcel) (Post et al., 2013; Gilfedder et al., 2019). As mixing is a linear process while radioactive decay and radioactive ingrowth are exponential (Bethke and Johnson, 2002), a systematic underestimation of the real mean age can occur if waters of different ages mix. One approach to circumvent this problem is the use of isotope ratios like, e.g., ${ }^{224} \mathrm{Ra} /{ }^{223} \mathrm{Ra}$. This method is very accurate if one water mixes with another one having zero activity (e.g., negligible $\mathrm{Ra}$ in freshwater) but does not work if the age difference between the water masses is large.

Residence time measurements tend to be point measurements at specific times. Verification of residence times based on radioisotopes is complicated to obtain. Comparing $\mathrm{Ra}$ - and $\mathrm{Rn}$-based residence times may be one approach (Tamborski et al., 2017). Alternatively, pore water residence times may be compared to those derived by the ratio of water volume in the STE and the water flux out of the STE (Colbert et al., 2008).

$\mathrm{Ra}$ and $\mathrm{Rn}$ isotopes can be combined with other tracers, such as temperature (Cranswick et al., 2014), salinity (Example in Figure 3), or dissolved silicon (DSi) (Waska and Kim, 2011; Oehler et al., 2019b). Since DSi behaves rather conservatively during transport through the STE, it can be used to trace processes that change other solutes in groundwater in STE, such as $\mathrm{N}$ or P (Oehler et al., 2019b). Another example is the combination of $\mathrm{CO}_{2}$ measurements and $\mathrm{Rn}$ measurements (e.g., Cyronak et al., 2014; Santos et al., 2015; Macklin et al., 2019). While this ties $\mathrm{CO}_{2}$ concentrations to SGD intensity, it does not yet differentiate if the $\mathrm{CO}_{2}$ is a product of STE processes or if the coastal groundwater just has elevated $\mathrm{CO}_{2}$ concentrations that originated from the terrestrial groundwater. Similarly, $\mathrm{CH}_{4}$ was combined with $\mathrm{Rn}$ as a tracer of SGD (Cable et al., 1996; Dulaiova et al., 2010) but could also be used for tracing processes in STE that generate $\mathrm{CH}_{4}$. Using $\mathrm{C}$ stable isotopes as a tracer (Winde et al., 2014; Donis et al., 2017) and considering elemental mass balances (Deines et al., 1974) may be a successful approach. 
The measurement of chemical tracers of STE processes at larger scales is associated with the problem to observe and measure the parameters with sufficient temporal and spatial resolution to resolve the underlying processes. Because tracer concentrations are modified upon emerging from the subsurface, sensors near the sea bottom are best suited to detect STE processes. The metabolites of typical benthic biogeochemical anaerobic $\mathrm{OM}$ degradation processes, like $\mathrm{Mn}^{2+}$ and $\mathrm{NH}_{4}^{+}$, may, after benthic-pelagic coupling, survive the oxidation within the oxic water column for some time (Kowalski et al., 2012; Winde et al., 2014). Since some liberated trace elements will be reoxidized and sorbed to suspended particles, regional investigations will have to consider both the dissolved and the solid phases (Kowalski et al., 2012). Whereas the dissolved substances may be detected using discrete or continuous sampling techniques (Petersen et al., 2011; Kowalski et al., 2012), solid-phase sampling for geochemical analysis is limited to discrete sampling. Measurements can also be performed by autonomous underwater vehicles, which could automatically trace signals, like temperature, conductivity or Rn-isotopes, of groundwater discharge and scout for STEs (Tholen et al., 2019).

New combinations of sensors would help to detect STEs. Optical spectrometers in the UV-visible range of the light spectrum can be used to determine the concentration of nitrate, nitrite, $\mathrm{HS}^{-}$, humic acids or DOC rapidly and without the use of reagents. It is to be expected that the optical absorption spectra will allow identifying water influenced by STEs. Sensors for the oxidation-reduction-potential (or, when referenced to the potential of a Standard Hydrogen Electrode, $E_{h}$ ) have been used for the estimation of concentrations of redoxsensitive elements in the redoxcline of the Baltic Sea (Meyer et al., 2014) or detecting hydrothermal plumes in the deep ocean (e.g., Baker et al., 2005). Combining several sensor types should allow the detection of STE signals in waters close to the bottom.

Geochemical tracers can help to regionally assess the amounts of SGD and point to the presence of STEs. They can also be applied at the local scale to draw quantitative conclusions about residence times in STEs and thus infer information about their reaction kinetics. At the regional scale, discrete and continuous measurements can be done. Still, these measurements will consist of discrete sampling points, and the feasibility of sampling will limit their resolution and coverage, which needs to be scaled according to the variability of the processes and tracers considered.

\section{Ecological Tracers}

Biodiversity in terrestrial groundwater recently received increased scientific attention (e.g., Hancock et al., 2005; Humphreys, 2008). Environmental gradients affect marine organisms in coastal waters. $\mathrm{N}$ and $\mathrm{P}$ are growth-limiting nutrients for most phytoplankton and macrophytes species that form the primary producers of the marine food web. Externally added nutrients alter the cycles of energy-flow between the pelagic and benthic zones, changing the community structure and population dynamics of both pelagic and benthic systems (Johannes, 1980; Sugimoto et al., 2017;
Grzelak et al., 2018). A similar adaption to an increase in the concentration of nutrients can also be observed in the case of changes in other physical or chemical parameters of the environment: salinity, amount of light in the water column, amount of $\mathrm{C}$ species, heavy metals, $\mathrm{O}_{2}$ concentration, the presence of hydrogen sulfide, or changes in $\mathrm{pH}$. For example, observed changes in the chemical composition of bioavailable $\mathrm{C}$ in the Yucatan coastal waters result in lower coral cover, smaller size and reduced species richness (Crook et al., 2012). Benthic meio- and macrofaunal organisms may react to changes in the environment. Differences in benthic microbiology were observed in STE compared to purely saline beach waters, but little is known about microbial communities in STE (Santoro et al., 2006; Santoro et al., 2008; Santoro, 2010; Adyasari et al., 2019a; Adyasari et al., 2020). Thus, depending on location or environmental factors, STE may change species richness and diversity of meiofauna (Kotwicki et al., 2014; Encarnação et al., 2015; Welti et al., 2015; Grzelak et al., 2018). Similarly, macrofaunal communities can respond; their biodiversity can increase due to food supply (Waska and Kim, 2010; Pisternick et al., 2020) or may be reduced due to salinity stress or changes in pH (Zipperle and Reise, 2005; Migné et al., 2011; Utsunomiya et al., 2017). However, while the named ecological responses can highlight an STE presence, they will be hard to interpret as tracers of processes within that STE.

Since the impact of microbially mediated biogeochemical processes in the physicochemical gradients of STEs can be diverse (e.g., Beck et al., 2011), it is useful to apply the established methods to study the communities of organisms and associated biogeochemical processes occurring in the entire ecosystem. Methods of assessing abundance, activity, biomass and diversity include taxonomic phytoplankton analyses in water samples, fauna and microbial activity analyses in sediment cores, or fish assessment in the water. For ecological studies on the impacts of processes in STEs, these methods are combined with thermal infrared cameras or $\mathrm{Ra} / \mathrm{Rn}$ tracing (Sugimoto et al., 2017; Grzelak et al., 2018). Simultaneous measurements of ${ }^{222} \mathrm{Rn}$ with other biological parameters allow assessing the reaction of biota activity on products of STEs (Taniguchi et al., 2019). Stable isotopes of N and $\mathrm{C}$ can also be used to trace STE products in the food web. Several studies have traced the behavior and fate of groundwater DIN using the isotope $\delta^{15} \mathrm{~N}$ of seagrass and macroalgae (Winde et al., 2017; Andrisoa et al., 2019) and gradients in the stable carbon isotope ratio between fresh and marine end-members (Gramling et al., 2003; Winde et al., 2017).

Consistent integration of hydrographic and biogeochemical research with bio-monitoring, elementary approaches and stable isotope analyses while considering higher trophic levels like fish and trophic flows in coastal ecosystems would enable the estimation of the direct impact of processes in STEs on ecosystems. While not yet done, specific species may have the potential to indicate STE processes in specific environments. Research in this direction is emerging (Lecher and Mackey, 2018), but additional knowledge is required before ecology can be used as a tracer for STE processes. 


\section{Geophysical Methods}

From a geophysical perspective, the changes of physical and geochemical conditions under the seafloor associated with the presence of STEs are detectable by measuring properties such as electrical conductivity (EC), acoustic impedance (AI), or temperature. STEs can affect 1) the seafloor itself, e.g., its morphology, 2) the sediment or rock below it and 3) the properties of the water column, e.g., turbidity or sea-surface temperature.

At the local scale, geophysical methods can delineate the shape of an STE in detail. The EC difference between the terrestrial groundwater and saltwater is the most prominent parameter for local scale geophysical STE observation. The EC of freshwater varies depending on the total amount of dissolved ions, and literature puts it below $300 \mu \mathrm{S} / \mathrm{cm}$ (Kirsch, 2006), 1,000 $\mathrm{SS} / \mathrm{cm}$ (Jiao and Post, 2019), or $2000 \mu \mathrm{S} / \mathrm{cm}$ (Langguth and Voigt, 2004). The EC of surficial seawater is orders of magnitude higher, > $40,000 \mu \mathrm{S} / \mathrm{cm}$, depending on the temperature and thus latitude (Tyler et al., 2017). However, mineral grains, clay aggregates and organic matter in the STE also affect EC and need to be considered. Particularly sediment porosity and clay content strongly influence the overall EC of the bulk (rocks plus groundwater) volume (Archie, 1942). The high EC of clay leads to the general challenge of distinguishing freshwater saturated clays from brackish water saturated sands that may have very similar EC values. Gamma radiation of potassium, thorium and uranium at the surface helps to distinguish between clayey and sandy sediments (Siemon et al., 2020), as does an acoustic impedance contrast that seismic methods can show.

Many approaches that use electromagnetic fields (EM) emitted and detected by coils are available to represent subsurface properties (frequency-domain EM, time-domain-EM and slingram/ground-conductivity meter: Kirsch, 2006). Frequencydomain (sinusoidal transmitter currents) and time-domain EM (on/off transmitter currents) are typically used to obtain depth resolution at a single measurement point or along transects (Auken et al., 2003). Moving ground-conductivity meters are used for fast lateral mapping of EC but with limited depth resolution (e.g., De Smedt et al., 2013). Locating freshwater and thus STEs, at the regional scale can be realized using airborne or ship-based EC measuring methods.

Airborne methods use helicopters or fixed-wing aircraft to carry the geophysical systems at about $20-100 \mathrm{~m}$ above ground, covering $100-200 \mathrm{~km}$ of profiles or typically $10-50 \mathrm{~km}^{2}$ per hour (Figure 4). In airborne EM, frequency-domain systems focus on near-surface (1-100 m) investigation of the spatial bulk EC (Siemon et al., 2015; Siemon et al., 2019; Siemon et al., 2020), whereas time-domain systems enable some deeper $(5-500 \mathrm{~m})$ investigation (Siemon et al., 2009; Steuer et al., 2009), depending on the conductivity distribution of the subsurface. Apart from electrical conductivity or resistivity, airborne radiometry maps the gamma radiation of the upper few decimeters of the surface (Wilford et al., 1997; IAEA, 2003). This technique has not yet been applied toward $\mathrm{Ra} / \mathrm{Rn}$ concentrations in seawater but might be a pathway forward to map those isotopes with broader spatial coverage. Besides, semiairborne methods using a ground-based transmitter and a helicopter-borne receiver have been developed recently to increase the penetration. While deep penetration is less important for STE investigation, UAV-based concepts can supplement the helicopter by a drone carrying the EM sensor in the future and hopefully enable cheaper investigations at the several kilometer scale. Finally, ship-based EM measurements have been applied to detect SGD (Müller, 2010; Müller et al., 2011).

Another EC method is electrical resistivity tomography (ERT), which, on land, uses steel electrodes pinned to the ground measuring the resistivity (the reciprocal of electrical conductivity) of the sediment by injecting a direct current (Stieglitz, 2005; Swarzenski et al., 2006). ERT has been used to observe the saltwater recirculation zone (Morrow et al., 2010) and its temporal changes (e.g., Johnson et al., 2015; Sutter and Ingham, 2017). ERT also can detect induced polarization effects caused by iron oxides (Mansoor and Slater, 2007). While this has not yet been applied to STEs, it could analyze $\mathrm{Fe}$-cycling in the mixing zone. Measurements of magneticresonance also provide information on iron oxides and their concentrations (Keating and Knight, 2007; Costabel et al., 2018) and provide subsurface porosity and hydraulic conductivity (e.g., Müller-Petke and Yaramanci, 2015).

Marine ship-based measurements of ERT tow floating or submerged streamers behind a boat (Manheim et al., 2004; Day-Lewis et al., 2006; Hermans and Paepen, 2020). A profile of $5 \mathrm{~km}$ length can be measured in $1 \mathrm{~h}$, but the conductive seawater limits penetration depth and therefore, streamer lengths of several hundred meters are needed to achieve sufficient penetration depth.

Seafloor morphological SGD proxies, such as pockmarks (e.g., Hoffmann et al., 2020), submarine terraces (Jakobsson et al., 2020), and depressions in carbonate rocks (Oehler et al., 2019a), are visible in the bathymetry. There are several techniques available to map the seafloor. Sidescan sonar data can reveal the location of pockmarks (e.g., Schlüter et al., 2004; Virtasalo et al., 2019), and echo sounders generally can also be applied for this task (Feldens et al., 2018; Papenmeier et al., 2020). Multibeam echo sounders provide high lateral coverage across-track on the seafloor, which is several times the water depth, enabling a fast mapping of larger scales.

Obtaining information on the geological structures by using high-resolution seismic profiling can be relevant for delineating the geometry of STEs (Mosher and Simpkin, 1999). The resulting image shows the reflection amplitudes and times (or depths) resulting from material interfaces with an impedance contrast, where the acoustic impedance is the product of bulk density and compressional velocity. Seismic profiles can be measured simultaneously with geoelectric streamers providing the same estimated profile length of $5 \mathrm{~km}$ per hour.

Geophysical methods also allow analyzing biogeochemical processes that occur within STEs, since some products can be identified. Shallow free gas accumulations (e.g., $\mathrm{CH}_{4}, \mathrm{~N}_{2}$ ) can be mapped on larger scales using multibeam echo sounders. Gas is visible as acoustic blanking, bright spots, acoustic turbidity, or gas chimneys in seismic data (Hovland and Judd, 1988; Judd and Hovland, 1992). Free gas can have multiple origins in the ocean, so SGD does not necessarily cause its occurrence. However, gasrelated features along the Belgian coast (Missiaen et al., 2002), in 


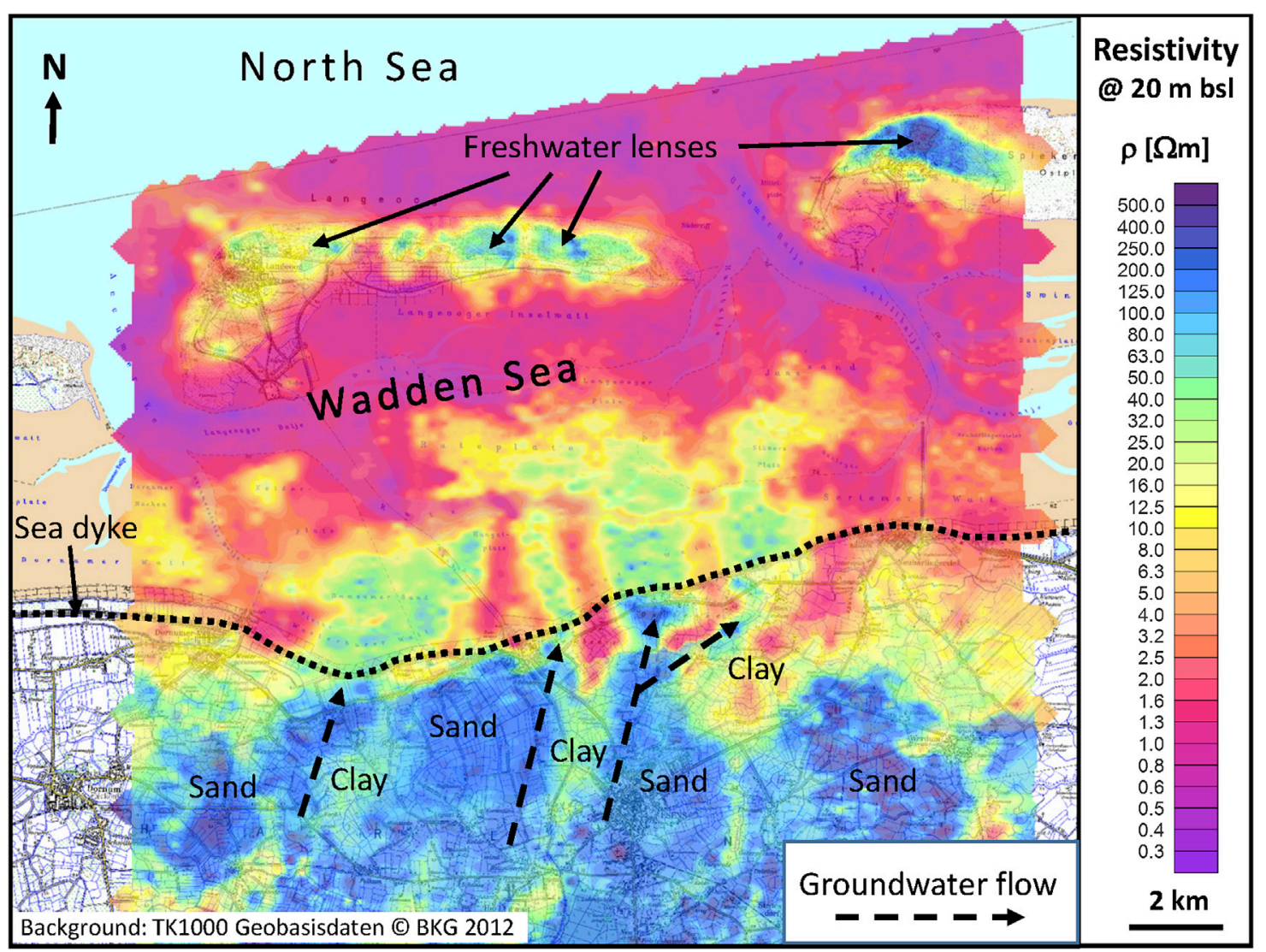

FIGURE 4 | Resistivities at $20 \mathrm{~m}$ below sea level derived from HEM inversion models indicating sandy and clayey areas, freshwater lenses on the islands of Langeoog and Spiekeroog and groundwater flow (dashed arrows) towards the Wadden Sea. The sea dyke is indicated by a dotted black line (data from BGR, 2017, background topographic map: BKG, 2012).

Brazil, Argentina and South Africa (Weschenfelder et al., 2016) and the North Yellow Sea (Wang et al., 2018) were linked to localized groundwater discharge.

Finding transfer functions linking discrete biogeochemical data and continuous geophysical methods is a promising methodology to extrapolate STE processes to the regional scale. In particular, methods going beyond the "classical" mapping of resistivity (Figure 4), which would allow to spot offshore freshening of pore water and thus STEs, have only rarely been applied to characterizing biogeochemical processes in STEs but show a substantial potential. A critical challenge is integrating local information into regional mapping by connecting different scales (point-like measurements, ground-based spatial information, airborne and satellite). Recent developments allow to include point-like or drilling information into ground-based geophysics using different concepts (e.g., Wunderlich et al., 2018) and coupling ground-based geophysics with airborne data (Dickson et al., 2014), providing perspectives for regional-scale assessments that are unviable based on ground-based measurements alone.

\section{Remote Sensing}

Remote sensing provides spatially continuous information on a scale from $10^{1}$ to $10^{9} \mathrm{~m}^{2}$ (Böttcher et al., 2021), depending on the platform (ground-based application, remotely operated vehicle, uncrewed erial vehicle (UAV), kite gyrocopter, airplane, satellite). The chosen scale constrains the ground resolution (ground sampling distance), which may vary between $10^{0}$ to $10^{2} \mathrm{~m}$. Scale and ground resolution intrinsically determine which STE indicator may be observed (Böttcher et al., 2021). Diffuse discharging groundwater is unlikely to be observed using satellite-based remote sensing, but can be observed with close-range applications or UAVs. However, the effort to cover regional scales is unequally larger for UAVs than for airplane- or satellite-based applications. Given the negligible depth penetration of remote sensing earth observation techniques in most situations, remote sensing can only investigate STE processes indirectly through its surface expressions. Remote sensing can detect terrestrial SGD, map seafloor and coastline morphology to find potential STEs, indicate hydrogeological STE characteristics, and identify STE processes by, e.g., classifying submerged aquatic vegetation that may be influenced by STEs.

Available sensors cover a wide range of the electromagnetic spectrum and can detect/differentiate surface properties that may act as indicators for STE processes or characteristics. The most commonly applied sensor in STE investigations is the thermal infrared (TIR) sensor, which can exploit temperature differences between seawater and terrestrial groundwater at the sea-surface (Figure 5). TIR detects groundwater inflow locations by 


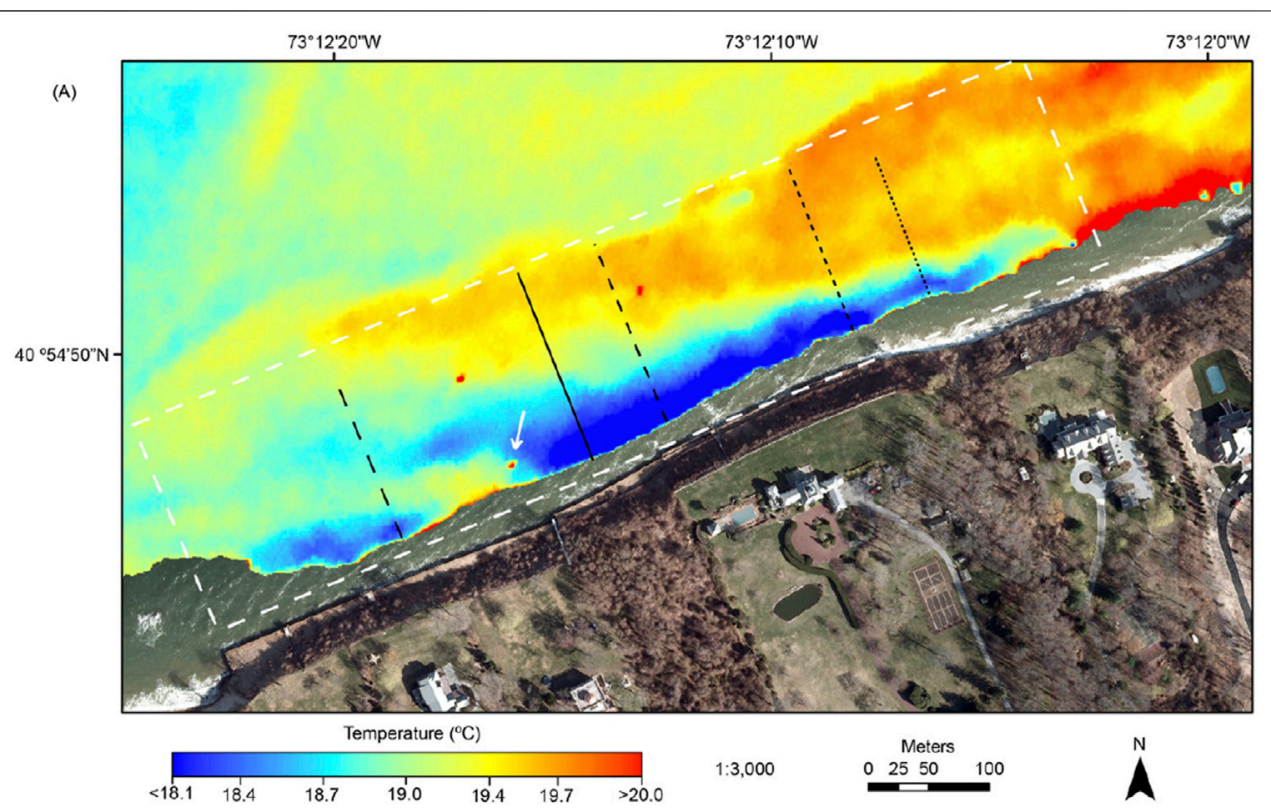

FIGURE 5 |TIR map displaying an area of cool diffuse seepage of terrestrial SGD that indicates an STE (Tamborski et al., 2015). Permission for reprint was provided by the copyright-holder.

identifying a thermal anomaly based on mono-temporal investigations (Fischer et al., 1964; Mejias et al., 2012; Wilson and Rocha, 2012; Kelly et al., 2013; Mallast et al., 2014; Xing et al., 2016), or multi-temporal investigations (Schubert et al., 2014; Oehler et al., 2018), and can be used to quantify freshwater fluxes given in-situ reference data of currents and bathymetry (Roseen, 2002; Johnson et al., 2008; Danielescu et al., 2009; Tamborski et al., 2015). The extent and shape of sea-surface temperature anomalies can indicate specific STE processes and characteristics (Chen, 1991; Jirka, 2004). Elongated anomalies oriented perpendicular to the coastline (Shaban et al., 2005) or extensive areas of thermal anomalies (Kelly et al., 2013) point to focused groundwater discharge at a high rate, suggesting a low residence time in STEs. Areas with smaller anomalies close to the coastline distributed over tens of meters alongshore (Tamborski et al., 2015) suggest diffuse discharge. The former is typical for karst or volcanic aquifers from which groundwater discharges along conduits, whereas the latter is commonly associated with sedimentary aquifers. Since higher temperature differences and distinct anomalies are easier to measure by TIR sensors, focused, high-volume discharge is more easily detected than slow, diffuse discharge.

Besides thermally identifying terrestrial groundwater discharge, remote sensing can classify benthic microbiology (e.g., Kazemipour et al., 2012) and submerged aquatic vegetation, which has been found to allow inferences about STEs (e.g., Leitão et al., 2015; Welti et al., 2015). While these observations are connected to local scale in-situ investigations, optical remote sensing using multi- and hyperspectral sensors (Klemas, 2016) has successfully been applied in shallow waters but not yet linked to potential terrestrial groundwater influence.

The relationship between STE characteristics indicated by seabed morphology and even operationally provided seafloor maps over regional scales using air- and satellite-borne platforms is similarly unexploited (Siermann et al., 2014; Eugenio et al., 2015). Remotely sensed bathymetry would allow a first-order approximation of potential pockmark sites. Since one of the forces that can produce pockmarks is fluid flow (Hovland et al., 2002), which can be an STE defining process, pockmarks can be seen as hinting toward the potential existence of STEs. Coastline morphology can be shaped by the same processes and may represent a similar indicator (Johannes, 1980).

A drawback of remote sensing methods is that it is challenging to link discrete, in-situ measurements to remote sensing data that integrate a multitude of effects other than those caused by an STE presence (e.g., ocean currents, chlorophyll presences). This weakness calls for a multi-scale approach (Lausch et al., 2013) in which an identified STE location is observed synchronously and over long periods with an appropriate in-situ sensor array and various airborne to satellite platforms covering different spatial scales. Such long-term sites could be associated with coastal observatories (Schofield et al., 2003) equipped with sensors to measure, e.g., turbidity, EC, $\mathrm{pH}$, oxygen level, and thus be investigated through interdisciplinary approaches (Mollenhauer et al., 2018).

Second, since the temporal variability of the STE-associated processes is high, an interesting approach would be to have a TIR remote sensing approach that enables a multi-temporal observation possibility. The recent advance of UAVs do provide such a possibility, as shown in Mallast and Siebert (2019), but cannot cover a regional scale simultaneously. The revisiting times will be reduced for Landsat with the launch of Landsat-9 in spring 2021 and the Indian-French THRISHNA mission, whose launch is planned for 2024 (Lagouarde et al., 2018). Nano-to mini-satellites can even revisit individual 
locations several times per day (Van Ryswyk, 2020). If these vehicles would also carry a TIR sensor and resemble a similarly very high ground resolution of $<3 \mathrm{~m}$, a regional to global scale localization of SGD sites and thus STE locations could become possible.

\section{Hydrogeological Modeling}

Another way to investigate STEs is through reactive transport models (RTMs), which remains underutilized in STE research (Robinson et al., 2017). Published modeling studies analyzed STEs as a high reactivity zones for, e.g., organic contaminants, nitrate and sulfate (Robinson et al., 2009; Anwar et al., 2014; Kim et al., 2017). The extent to which reactions proceeded was dependent on the degree of dispersive mixing and residence time in the STE, which was controlled by hydrological boundary conditions, such as terrestrial groundwater flux, beach slope and tidal amplitude. Another modeling study also showed the importance of dispersive mixing in STE on organic contaminant removal from groundwater (Nick et al., 2013).

The RTMs mentioned above provided process understanding but lacked confirmation by field data. There are only two field sites where RTMs and observations were integrated. The studies at Waquoit Bay by Spiteri et al. (2008a), Spiteri et al. (2008b), and Spiteri et al. (2008c), formed the earliest applications of RTMs of the STE and showed that the $\mathrm{pH}$ change at the interface between terrestrial groundwater and the lower saltwater wedge is an essential factor that controls the oxidation of $\mathrm{Fe}^{2+}$ and subsequent adsorption of land derived phosphorus (Spiteri et al., 2008a). Further, model results suggested that enhanced nutrient turnover occurs close to the SGD exit point due to high transverse dispersive mixing of oxic and anaerobic groundwater, resulting from converging groundwater flow toward the sea (Spiteri et al., 2008b; Spiteri et al., 2008c). The other site where model simulations were used to support field data interpretation is at Cape Henlopen, Delaware, USA (Kim et al., 2017). At this site, the field data showed that aerobic respiration led to a depletion of oxygen within the upper saline plume and that nitrate concentrations were lowest where ammonium and particulate organic carbon were highest. Even though their numerical model was able to simulate the general spatial $\mathrm{O}_{2}$ and $\mathrm{N}_{2}$ concentration trends, discrepancies remained evident, which the authors attributed to uncaptured heterogeneity and transient processes, as well as the omission of iron and sulfate reduction processes in the model. Thus, this is an example of the difficulties to model STEs due to their high spatial complexity. Modeling can also be applied in combination with isotopic data to elucidate reliable dating information on the STE water age (Bethke and Johnson, 2008; Post et al., 2019), which could provide information for reaction rates.

It is unlikely that numerical, reactive transport models of biogeochemical reactions in STEs can be applied with any reasonable expectation of success at the regional scale. The first reason is that the computational resources required will remain prohibitive in the foreseeable future. The second and perhaps foremost reason is that the input data requirements are unattainable at the regional scale due to the high spatial and temporal variability of STEs. Therefore, regional-scale models of
STE nutrient transformations will have to rely on simplified process representations that can be parametrized with input data obtainable at a reasonable effort and cost. There are several essential questions to consider, including: What is an appropriate spatial level of heterogeneity for capturing regional scale processes that could be similar to the representative elementary volume (REV) concept for groundwater flow (cf. Freeze, 1975)? How can processes be integrated along the vertical dimension? How to account for local-scale variability? What is the temporal variability at the intra- and inter-annual scale? Can coastal landscape units be classified according to their geochemical reactivity?

Concerning the last question, one feasible approach to upscale modeling of STE processes might be to identify distinctive zones where controlling factors on the reactions are relatively uniform and then use small-scale model information to extrapolate to a regional-scale area. Working with distinctive uniform zones would imply a classification (e.g., Bokuniewicz et al., 2003). However, levels of homogeneity representative for larger areas are not yet adequately defined, as is the answer to whether and how small-scale temporal variations extrapolate into a larger scale. The terrestrial component of SGD was already modeled at the regional scale (Jarsjö et al., 2008; Befus et al., 2017; Hajati et al., 2019) and global scale (Zhou et al., 2019; Luijendijk et al., 2020) using similar approaches. These models produce spatially explicit estimates of terrestrial SGD that is a necessary prerequisite for STEs. Local scale RTMs highlight the importance of understanding mixing (hydrodynamic dispersion) and sediment organic carbon content, so it would seem reasonable to expect that these at least will have to be accounted for at the regional scale as well. Both are linked to sediment heterogeneity (regarding hydraulic properties and geochemistry) and the variability of hydraulic gradients so that the starting point would be a deterministic understanding of the longshore geological variability and a mechanistic description of the driving forces.

Data products of sufficient quality that represent controls of STE processes are required to model STE processes on the regional scale. The amount of data available at a global scale and high resolution is quickly increasing, but many aspects are not yet adequately covered. Foremost, since STEs occur along the coast, a high-resolution coastline is necessary and available (Sayre et al., 2018). STE sediment properties can be represented by recent datasets focusing on coastal sediment heterogeneity (de Graaf et al., 2017; Zamrsky et al., 2020). Other datasets focusing on the terrestrial aquifer (Gleeson et al., 2014) or marine sediment thickness (Straume et al., 2019) and its properties (Dutkiewicz et al., 2016) are hardly useable at the coast due to their global focus and low spatial resolution. Additional hydrogeological background knowledge would be, e.g., tectonic activity or stress maps, where areas of high tectonic activity would contain more faults and thus more potential pathways for groundwater.

Mixing intensity and processes in STEs will also be controlled by the amount of freshwater discharging (Luijendijk et al., 2020) or the amount of seawater recirculating (Mayfield et al., 2021). Water quality of the incoming freshwater is not known at a global 


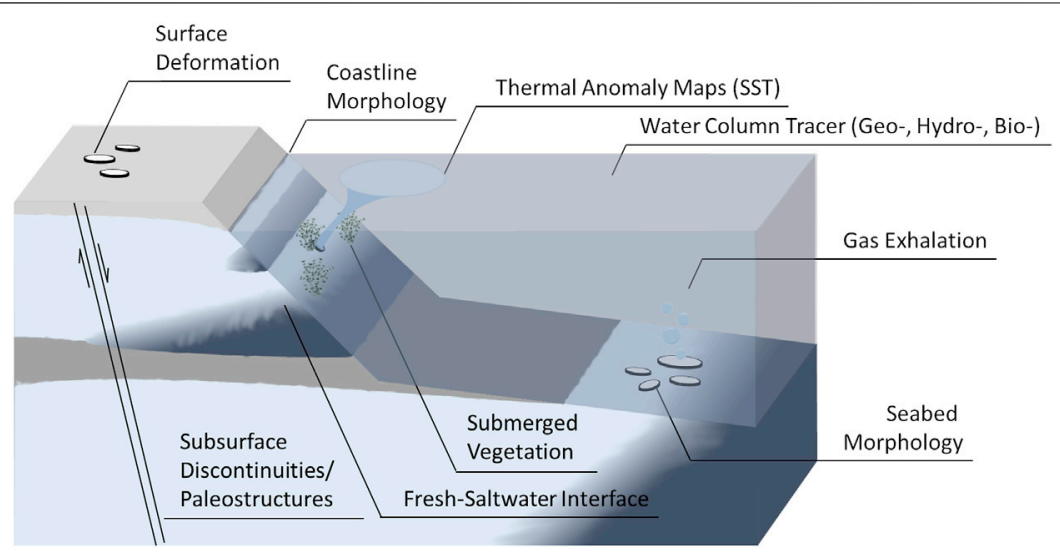

FIGURE 6 | Consequences of hydro (geo)logical and biogeochemical processes in STEs that can be used for extrapolation to the regional scale.

scale, but, as a first crude guess, could be inferred by proxy, e.g., from land-cover (e.g., Arino et al., 2007) or soil (FAOIIASA, ISRIC et al., 2009) datasets. Another option would be to extrapolate from datasets of multiple local groundwater quality measurements (e.g., NAWQA from USGS). In any case, groundwater quality is far less constrained than aquifer properties at large scales. Synthesized data sets of geological and geochemical properties of the subsurface below the seafloor on a regional scale are virtually absent.

Any of the large-scale datasets available have problems resolving the spatial heterogeneity of coasts, so the resulting estimates will not be applicable at the local scale (Geng et al., 2020) but provide first-order estimates for larger scales. This problem is not unique to the coast (e.g., Moosdorf et al., 2010) but amplified by the steep gradients in that setting. Given that the uncertainty of any model-based estimate is going to be very large, rather than focusing on the accuracy of the absolute numbers, it would be preferable to develop approaches that reveal the lateral differences. Such an approach would allow the ranking of different areas in terms of their effect on the coastal systems, highlighting hotspots to be targeted by more detailed investigations or specific measures.

\section{CONCLUSIONS AND PERSPECTIVE}

This review of biogeochemical processes in subterranean estuaries highlighted the spatial and temporal variability of these systems. Their reactions and corresponding rates depend on the hydrology of the STEs and the chemical composition of sediments and source waters (terrestrial groundwater and seawater). These controls have to be constrained to budget the processes within STEs and estimate the regional scale effects of STEs.

Characterizing STEs at the regional scale can be achieved through their products (Figure 6). The first step of estimating STE activity at a regional scale is to identify locations, amount, and the general extent of STEs. Locations can be identified through continuous measurements of geochemical tracers, e.g., electrical conductivity or $\mathrm{Ra} / \mathrm{Rn}$ isotopes in the ocean.
Biological indicators can point to the existence of STEs. Geophysical methods can provide information about freshened pore water and gas occurrences below the seafloor. Hydrogeological modeling can also estimate the flow behavior, but the necessary data are usually not available to represent larger areas in numerical 3D models realistically. Remote sensing information, for example, TIR images, can additionally show thermal signatures of freshwater influx. Combining observational methods from different disciplinary backgrounds, paired with modeling and hydrogeological data, is most promising for a regional scale effort to locate STEs.

Products of biogeochemical processes can be used to trace processes occurring in STEs (Figure 6). These products can be specific chemicals, like, e.g., $\mathrm{CO}_{2}, \mathrm{~N}_{2}$ gas or $\mathrm{Mn}^{2+}$, but also isotopic tracers like $\delta 13 \mathrm{C}$ in DIC, $\delta 18 \mathrm{O}$ and $\delta 15 \mathrm{~N}$ in nitrate, as well as $\delta 2 \mathrm{D}$ and $\delta 18 \mathrm{O}$ in water. With geophysical methods, gaseous products of STEs can be identified, as well as iron oxides in the sediment, which are an essential control on the biogeochemistry of STEs. Remote sensing allows tracing changes in sea bottom that could indicate properties of the STEs in some cases. Nevertheless, since processes in STEs are spatially and temporally highly variable, discrete in-situ observations of specific STE products (e.g., $\mathrm{CO}_{2}, \mathrm{~N}_{2}$, or $\mathrm{Mn}^{2+}$ ) need to be combined with temporally and spatially continuous and temporally higher resolved data (e.g., remote sensing) using transfer functions.

Reactive transport models (RTM) can act as temporal and spatial link between discrete local scale in-situ measurements and spatially continuous regional scale data to extrapolate STE processes onto larger scales. To account for the high variability, quantitative local scale measurements will have to be combined with the concept of representative elementary volume (REV) based on regional-scale data sets such as from geophysical measurements or maps containing hydrogeological information. An RTM would represent each REV to quantify fluxes at scales relevant to the coastal zone and coastal zone management. On that basis, it would be even possible to sort STEs in classes when discussing their regional impact. Particularly, STEs with diffuse porous flow need to be distinguished from STEs in conduits, e.g., in karstic or volcanic settings. 
A combination of methods from the presented disciplines promises a pathway toward regional scale estimates of processes in STEs and their impact on land-ocean matter fluxes. That impact may be substantial since local scale studies strongly hint toward their relevance. The processes are known; the products are known; the methods are available. Now is the time to combine methods across disciplines and understand these critical processes.

\section{AUTHOR CONTRIBUTIONS}

NM conceived the paper and wrote about upscaling; NM and UM coordinated the paper; UM, HW, and NM got funding for the project; MEB, BG, DA, A-KJ, TO, RP, JS, CE, and HW, contributed the biogeochemical part; LK contributed the biological part; EE, MM-P, BS, and TW, contributed the geophysical part; JG, GM, VP, and MW, contributed the hydrogeological modeling part; UM contributed the remote sensing part. All authors contributed to writing the manuscript and discussing the concept and formulating the overarching themes.

\section{REFERENCES}

Abarca, E., Karam, H., Hemond, H. F., and Harvey, C. F. (2013). Transient groundwater dynamics in a coastal aquifer: the effects of tides, the lunar cycle, and the beach profile. Water Resour. Res. 49 (5), 2473-2488. doi:10.1002/wrcr. 20075

Adyasari, D., Hassenrück, C., Montiel, D., and Dimova, N. (2020). Microbial community composition across a coastal hydrological system affected by submarine groundwater discharge (SGD). PLOS ONE 15 (6), e0235235. doi:10.1371/journal.pone.0235235

Adyasari, D., Hassenrück, C., Oehler, T., Sabdaningsih, A., and Moosdorf, N. (2019). Microbial community structure associated with submarine groundwater discharge in northern Java (Indonesia). Sci. Total Environ. 689, 590-601. doi:10.1016/j.scitotenv.2019.06.193

Adyasari, D., Oehler, T., Afiati, N., and Moosdorf, N. (2019). Environmental impact of nutrient fluxes associated with submarine groundwater discharge at an urbanized tropical coast. Estuarine, Coastal Shelf Sci. 221, 30-38. doi:10. 1016/j.ecss.2019.03.009

Akam, S. A., Coffin, R. B., Abdulla, H. A. N., and Lyons, T. W. (2020). Dissolved inorganic carbon pump in methane-charged shallow marine sediments: state of the art and new model perspectives. Front. Mar. Sci. 7. doi:10.3389/fmars.2020. 00206

Al-Raei, A. M., Bosselmann, K., Böttcher, M. E., Hespenheide, B., and Tauber, F. (2009). Seasonal dynamics of microbial sulfate reduction in temperate intertidal surface sediments: controls by temperature and organic matter. Ocean Dyn. 59 (2), 351-370. doi:10.1007/s10236-009-0186-5

Alorda-Kleinglass, A., Garcia-Orellana, J., Rodellas, V., Cerdà-Domènech, M., Tovar-Sánchez, A., Diego-Feliu, M., et al. (2019). Remobilization of dissolved metals from a coastal mine tailing deposit driven by groundwater discharge and porewater exchange. Sci. Total Environ. 688, 1359-1372. doi:10.1016/j. scitotenv.2019.06.224

Andrisoa, A., Stieglitz, T. C., Rodellas, V., and Raimbault, P. (2019). Primary production in coastal lagoons supported by groundwater discharge and porewater fluxes inferred from nitrogen and carbon isotope signatures. Mar. Chem. 210, 48-60. doi:10.1016/j.marchem.2019.03.003

Anschutz, P., Smith, T., Mouret, A., Deborde, J., Bujan, S., Poirier, D., et al. (2009). Tidal sands as biogeochemical reactors. Estuarine Coastal Shelf Sci. 84 (1), 84-90. doi:10.1016/j.ecss.2009.06.015

Anwar, N., Robinson, C., and Barry, D. A. (2014). Influence of tides and waves on the fate of nutrients in a nearshore aquifer: numerical simulations. Adv. Water Resour. 73, 203-213. doi:10.1016/j.advwatres.2014.08.015

\section{ACKNOWLEDGMENTS}

This publication is a result of the DFG supported KiSNet project (MA7041/6-1). MEB and AKJ wish to thank DFG for financial support during research training group BALTIC TRANSCOAST (GRK 2000) and MEB and CvA the DAAD for a Ph.D. stipend for a stay of CvA at IOW. This is BALTIC TRANSCOAST publication No. GRK 2000/0045. HW was funded by the Niedersächsisches Ministerium für Wissenschaft und Kultur (MWK) in the scope of project "BIME" (ZN3184). JS acknowledges the support through the SEAMOUNT BONUS project (art. 185), which is funded jointly by the EU and the Federal Ministry of Education and Research of Germany (BMBF, Grant Nos. 03F0771B). The authors acknowledge the helpful review comments by D. Brankovits, G. Chaillou and A. Pain, and the editorial handling by F. Frappart. Finally, the authors would like to express their gratitude to Bill Burnett, who turns 75 this year. Bill inspired many of us to pursue research in the field of SGD and supported wherever he could. Thank you, Bill.

Archie, G. E. (1942). The electrical resistivity log as an aid in determining some reservoir characteristics. Trans. Am. Inst. Mining Metallurgical Eng. 146, 54-62. doi:10.2118/942054-g

Arino, O., Gross, D., Ranera, F., Bourg, L., Leroy, M., Bicheron, P., et al. (2007). GlobCover: ESA service for global land cover from MERIS. Proceedings of the international geoscience and remote sensing symposium (IGARSS) 2007. Barcelona: IEEE International, 2412-2415.

Auken, E., Jørgensen, F., and Sørensen, K. I. (2003). Large-scale TEM investigation for groundwater. Exploration Geophys. 34 (3), 188-194. doi:10.1071/eg0318

Baker, E. T., Massoth, G. J., Nakamura, K.-i., Embley, R. W., de Ronde, C. E. J., and Arculus, R. J. (2005). Hydrothermal activity on near-arc sections of back-arc ridges: results from the mariana trough and lau basin. Geochem. Geophys. Geosystems 6 (9). doi:10.1029/2005gc000948

Balzer, W. (1982). On the distribution of iron and manganese at the sediment/ water interface: thermodynamic versus kinetic control. Geochim. Cosmochim. Acta 46 (7), 1153-1161. doi:10.1016/0016-7037(82)90001-1

Beck, A. J., Charette, M. A., Cochran, J. K., Gonneea, M. E., and PeuckerEhrenbrink, B. (2013). Dissolved strontium in the subterranean estuary implications for the marine strontium isotope budget. Geochim. Cosmochim. Acta 117, 33-52. doi:10.1016/j.gca.2013.03.021

Beck, A. J., Cochran, J. K., and Sanudo-Wilhelmy, S. A. (2010). The distribution and speciation of dissolved trace metals in a shallow subterranean estuary. Mar. Chem. 121 (1-4), 145-156. doi:10.1016/j.marchem.2010.04.003

Beck, A. J., and Cochran, M. A. (2013). Controls on solid-solution partitioning of radium in saturated marine sands. Mar. Chem. 156, 38-48. doi:10.1016/j. marchem.2013.01.008

Beck, A. J., Kellum, A. A., Luek, J. L., and Cochran, M. A. (2016). Chemical flux associated with spatially and temporally variable submarine groundwater discharge, and chemical modification in the subterranean estuary at gloucester point, VA (USA). Estuaries Coasts 39 (1), 1-12. doi:10.1007/ s12237-015-9972-0

Beck, A. J., Tsukamoto, Y., Tovar-Sanchez, A., Huerta-Diaz, M., Bokuniewicz, H. J., and Sañudo-Wilhelmy, S. A. (2007). Importance of geochemical transformations in determining submarine groundwater discharge-derived trace metal and nutrient fluxes. Appl. Geochem. 22 (2), 477-490. doi:10. 1016/j.apgeochem.2006.10.005

Beck, M., and Brumsack, H.-J. (2012). Biogeochemical cycles in sediment and water column of the Wadden Sea: the example Spiekeroog Island in a regional context. Ocean Coastal Manag. 68, 102-113. doi:10.1016/j.ocecoaman.2012. 05.026

Beck, M., Reckhardt, A., Amelsberg, J., Bartholomä, A., Brumsack, H.-J., Cypionka, H., et al. (2017). The drivers of biogeochemistry in beach ecosystems: a cross- 
shore transect from the dunes to the low-water line. Mar. Chem. 190, 35-50. doi:10.1016/j.marchem.2017.01.001

Beck, M., Riedel, T., Graue, J., Köster, J., Kowalski, N., Wu, C. S., et al. (2011). Imprint of past and present environmental conditions on microbiology and biogeochemistry of coastal Quaternary sediments. Biogeosciences 8 (1), 55. doi:10.5194/bg-8-55-2011

Befus, K. M., Kroeger, K. D., Smith, C. G., and Swarzenski, P. W. (2017). The magnitude and origin of groundwater discharge to eastern U.S. And Gulf of Mexico coastal waters. Geophys. Res. Lett. 44 (20), 396-410. doi:10.1002/ $2017 \mathrm{gl} 075238$

Begemann, F., and Libby, W. F. (1957). Continental water balance, ground water inventory and storage times, surface ocean mixing rates and world-wide water circulation patterns from cosmic-ray and bomb tritium. Geochim. Cosmochim. Acta 12 (4), 277-296. doi:10.1016/0016-7037(57)90040-6

Bethke, C. M., and Johnson, T. M. (2008). Groundwater age and groundwater age dating. Annu. Rev. Earth Planet. Sci. 36 (1), 121-152. doi:10.1146/annurev. earth.36.031207.124210

Bethke, C. M., and Johnson, T. M. (2002). Paradox of groundwater age. Geology 30 (2), 107-110. doi:10.1130/0091-7613(2002)030<0107:poga >2.0.co;2

Beusen, A. H. W., Slomp, C. P., and Bouwman, A. F. (2013). Global land-ocean linkage: direct inputs of nitrogen to coastal waters via submarine groundwater discharge. Environ. Res. Lett. 8 (3), 034035. doi:10.1088/1748-9326/8/3/034035

BGR (2017). Helicopter-borne Electromagnetics (HEM) German North Sea coast Models. Bundesanstalt für Geowissenschaften und Rohstoffe (BGR), Hannover, Germany: doi:10.25928/bgr2017heminv_22v5-bg06

Billerbeck, M., Werner, U., Polerecky, L., Walpersdorf, E., deBeer, D., and Huettel, M. (2006). Surficial and deep pore water circulation governs spatial and temporal scales of nutrient recycling in intertidal sand flat sediment. Mar. Ecol. Prog. Ser. 326, 61-76. doi:10.3354/meps326061

Bishop, R. E., Humphreys, W. F., Kršinić, F., Sket, B., Iliffe, T. M., Žic, V., et al. (2015). 'Anchialine' redefined as a subterranean estuary in a crevicular or cavernous geological setting. J. Crustacean Biol. 35 (4), 511-514. doi:10.1163/ 1937240x-00002335

BKG (2012). Rasterdaten Topographische Karte 1:100000 (DTK1000). Bundesamt für Kartographie und Geodäsie (BKG), Frankfurt, Germany: Available at https://www.geodatenzentrum.de [Last accessed on July 3, 2012].

Blöschl, G., Bierkens, M. F. P., Chambel, A., Cudennec, C., Destouni, G., Fiori, A., et al. (2019). Twenty-three unsolved problems in hydrology (UPH)-a community perspective. Hydrol. Sci. J.-J. Des Sci. Hydrologiques 64 (10), $1141-1158$.

Boehm, A. B., Yamahara, K. M., and Sassoubre, L. M. (2014). Diversity and transport of microorganisms in intertidal sands of the California coast. Appl. Environ. Microbiol. 80 (13), 3943-3951. doi:10.1128/AEM.00513-14

Boetius, A., Ravenschlag, K., Schubert, C. J., Rickert, D., Widdel, F., Gieseke, A., et al. (2000). A marine microbial consortium apparently mediating anaerobic oxidation of methane. Nature 407 (6804), 623-626. doi:10. $1038 / 35036572$

Bokuniewicz, H., Buddemeier, R., Maxwell, B., and Smith, C. (2003). The typological approach to submarine groundwater discharge (SGD). Biogeochemistry 66 (1, 2), 145-158. doi:10.1023/b:biog.0000006125.10467.75

Bokuniewicz, H., Cochran, J. K., Garcia-Orellana, J., Rodellas, V., Daniel, J. W., and Heilbrun, C. (2015). Intertidal percolation through beach sands as a source of 224,223Ra to Long Island Sound, New York, and Connecticut, United States. J. Mar. Res. 73, 123-140. doi:10.1357/002224015816665570

Bone, S. E., Charette, M. A., Lamborg, C. H., and Gonneea, M. E. (2007). Has submarine groundwater discharge been overlooked as a source of mercury to coastal waters?. Environ. Sci. Technol. 41 (9), 3090-3095. doi:10.1021/ es0622453

Bone, S. E., Gonneea, M. E., and Charette, M. A. (2006). Geochemical cycling of arsenic in a coastal aquifer. Environ. Sci. Technol. 40 (10), 3273-3278. doi:10. $1021 / \mathrm{es} 052352 \mathrm{~h}$

Böttcher, M. E., and Dietzel, M. (2010). Metal-ion partitioning during lowtemperature precipitation and dissolution of anhydrous carbonates and sulphates. EMU Notes in Mineral. 10, 139-187. doi:10.1180/EMU-notes.10.4

Böttcher, M.E., Mallast, U., Massmann, G., Moosdorf, N., Mueller-Pethke, M., and Waska, H. (2021). "Coastal-Groundwater interfaces (submarine groundwater discharge)," in Ecohydrological interfaces. Editors S. Krause, D. M. Hannah, and N. Grimm (New York, NY: Wiley \& Sons).
Bögli, A., (1980). Karst hydrology and physical speleology. Berlin, UK: Springer, xiii, 284

Brando, V. E., and Dekker, A. G. (2003). Satellite hyperspectral remote sensing for estimating estuarine and coastal water quality. IEEE Trans. Geosci. Remote Sensing 41 (6), 1378-1387. doi:10.1109/tgrs.2003.812907

Brankovits, D., Pohlman, J. W., Niemann, H., Leigh, M. B., Leewis, M. C., Becker, K. W., et al. (2017). Methane- and dissolved organic carbon-fueled microbial loop supports a tropical subterranean estuary ecosystem. Nat. Commun. 8, 1835. doi:10.1038/s41467-017-01776-x

Brankovits, D., Pohlman, J. W., Ganju, N. K., Iliffe, T. M., Lowell, N., Roth, E., et al. (2018). Hydrologic controls of methane dynamics in karst subterranean estuaries. Glob. Biogeochem. Cycles 32 (12), 1759-1775. doi:10.1029/ $2018 \mathrm{gb} 006026$

Brankovits, D., and Pohlman, J. W. (2020). Methane oxidation dynamics in a karst subterranean estuary. Geochim. Cosmochim. Acta 277, 320-333. doi:10.1016/j. gca.2020.03.007

Brovelli, A., Mao, X., and Barry, D. A. (2007). Numerical modeling of tidal influence on density-dependent contaminant transport. Water Resour. Res. 43 (10). doi:10.1029/2006wr005173

Brown, K. I., and Boehm, A. B. (2016). Transport of fecal indicators from beach sand to the surf zone by recirculating seawater: laboratory experiments and numerical modeling. Environ. Sci. Technol. 50 (23), 12840-12847. doi:10.1021/ acs.est.6b02534

Burnett, W. C., Aggarwal, P. K., Aureli, A., Bokuniewicz, H., Cable, J. E., Charette, M. A., et al. (2006). Quantifying submarine groundwater discharge in the coastal zone via multiple methods. Sci. Total Environ. 367 (2, 3), 498-543. doi:10.1016/j.scitotenv.2006.05.009

Burnett, W. C., and Dulaiova, H. (2003). Estimating the dynamics of groundwater input into the coastal zone via continuous radon-222 measurements. J. Environ. Radioact. 69 (1, 2), 21-35. doi:10.1016/S0265-931X(03)00084-5

Burnett, W. C., Bokuniewicz, H., Huettel, M., Moore, W. S., and Taniguchi, M. (2003). Groundwater and pore water inputs to the coastal zone. Biogeochemistry 66 (1-2), 3-33. doi:10.1023/b:biog.0000006066.21240.53

Burton, E. A., and Walter, L. M. (1990). The role of $\mathrm{pH}$ in phosphate inhibition of calcite and aragonite precipitation rates in seawater. Geochim. Cosmochim. Acta 54 (3), 797-808. doi:10.1016/0016-7037(90)90374-t

Cable, J. E., Bugna, G. C., Burnett, W. C., and Chanton, J. P. (1996). Application of $222 \mathrm{Rn}$ and $\mathrm{CH} 4$ for assessment of groundwater discharge to the coastal ocean. Limnol. Oceanogr. 41 (6), 1347-1353. doi:10.4319/lo.1996.41.6.1347

Canfield, D. E., Glazer, A. N., and Falkowski, P. G. (2010). The evolution and future of Earth's nitrogen cycle. Science 330 (6001), 192-196. doi:10.1126/science. 1186120

Cerdà-Domènech, M., Rodellas, V., Folch, A., and Garcia-Orellana, J. (2017). Constraining the temporal variations of $\mathrm{Ra}$ isotopes and $\mathrm{Rn}$ in the groundwater end-member: implications for derived SGD estimates. Sci. Total Environ. 595, 849-857. doi:10.1016/j.scitotenv.2017.03.005

Chambers, R. M., and Odum, W. E. (1990). Porewater oxidation, dissolved phosphate and the iron curtain - iron-phosphorus relations in tidal freshwater marshes. Biogeochemistry 10 (1), 37-52. doi:10.1007/bf00000891

Charbonnier, C., Anschutz, P., Poirier, D., Bujan, S., and Lecroart, P. (2013). Aerobic respiration in a high-energy sandy beach. Mar. Chem. 155, 10-21. doi:10.1016/j.marchem.2013.05.003

Charette, M. A., Sholkovitz, E. R., and Hansel, C. M. (2005). Trace element cycling in a subterranean estuary: Part 1. Geochemistry of the permeable sediments. Geochim. Cosmochim. Acta 69 (8), 2095-2109. doi:10.1016/j.gca.2004.10.024

Charette, M. A., and Sholkovitz, E. R. (2002). Oxidative precipitation of groundwater-derived ferrous iron in the subterranean estuary of a coastal bay. Geophys. Res. Lett. 29 (10). doi:10.1029/2001gl014512

Charette, M. A., and Sholkovitz, E. R. (2006). Trace element cycling in a subterranean estuary: Part 2. Geochemistry of the pore water. Geochim. Cosmochim. Acta 70 (4), 811-826. doi:10.1016/j.gca.2005.10.019

Chen, H.-B. (1991). Turbulent buoyant jets and plumes in flowing ambient environments. Aalborg, Denmark: Department of Civil Engineering, University of Aalborg.

Chen, X., Cukrov, N., Santos, I. R., Rodellas, V., Cukrov, N., and Du, J. (2020). Karstic submarine groundwater discharge into the Mediterranean: radon-based nutrient fluxes in an anchialine cave and a basin-wide upscaling. Geochim. Cosmochim. Acta 268, 467-484. doi:10.1016/j.gca.2019.08.019 
Chevis, D. A., Johannesson, K. H., Burdige, D. J., Tang, J., Bradley Moran, S., and Kelly, R. P. (2015). Submarine groundwater discharge of rare earth elements to a tidally-mixed estuary in Southern Rhode Island. Chem. Geol. 397 (0), 128-142. doi:10.1016/j.chemgeo.2015.01.013

Cho, H.-M., and Kim, G. (2016). Determining groundwater Ra end-member values for the estimation of the magnitude of submarine groundwater discharge using $\mathrm{Ra}$ isotope tracers. Geophys. Res. Lett. 43 (8), 3865-3871. doi:10.1002/ $2016 \mathrm{gl} 068805$

Cho, H. M., Kim, G., Kwon, E. Y., Moosdorf, N., Garcia-Orellana, J., and Santos, I. R. (2018). Radium tracing nutrient inputs through submarine groundwater discharge in the global ocean. Sci. Rep. 8 (1), 2439-2446. doi:10.1038/s41598018-20806-2

Cho, H. M., Kim, T. H., Moon, J. H., Song, B. C., Hwang, D. W., Kim, T., et al. (2021). Estimating submarine groundwater discharge in Jeju volcanic island (Korea) during a typhoon (Kong-rey) using humic-fluorescent dissolved organic matter-Si mass balance. Sci. Rep. 11 (1), 941. doi:10.1038/s41598020-79381-0

Church, T. M. (1996). An underground route for the water cycle. Nature 380 (6575), 579-580. doi:10.1038/380579a0

Clark, I. D., and Fritz, P. (1997). Environmental isotopes in hydrogeology. London, NewYork, CRC Press.

Colbert, S. L., Berelson, W. M., and Hammond, D. E. (2008). Radon-222 budget in Catalina Harbor, California: 2. Flow dynamics and residence time in a tidal beach. Limnol. Oceanogr. 53 (2), 659-665. doi:10.4319/lo.2008.53.2.0659

Costabel, S., Weidner, C., Müller-Petke, M., and Houben, G. (2018). Hydraulic characterisation of iron-oxide-coated sand and gravel based on nuclear magnetic resonance relaxation mode analyses. Hydrol. Earth Syst. Sci. 22 (3), 1713-1729. doi:10.5194/hess-22-1713-2018

Couturier, M., Nozais, C., and Chaillou, G. (2016). Microtidal subterranean estuaries as a source of fresh terrestrial dissolved organic matter to the coastal ocean. Mar. Chem. 186, 46-57. doi:10.1016/j.marchem.2016.08.001

Couturier, M., Tommi-Morin, G., Sirois, M., Rao, A., Nozais, C., and Chaillou, G. (2017). Nitrogen transformations along a shallow subterranean estuary. Biogeosciences 14 (13), 3321-3336. doi:10.5194/bg-14-3321-2017

Cranswick, R. H., Cook, P. G., and Lamontagne, S. (2014). Hyporheic zone exchange fluxes and residence times inferred from riverbed temperature and radon data. J. Hydrol. 519, 1870-1881. doi:10.1016/j.jhydrol.2014. 09.059

Crook, E. D., Potts, D., Rebolledo-Vieyra, M., Hernandez, L., and Paytan, A. (2012). Calcifying coral abundance near low-pH springs: implications for future ocean acidification. Coral Reefs 31 (1), 239-245. doi:10.1007/s00338-011-0839-y

Cyronak, T., Santos, I. R., Erler, D. V., Maher, D. T., and Eyre, B. D. (2014). Drivers ofpCO2variability in two contrasting coral reef lagoons: the influence of submarine groundwater discharge. Glob. Biogeochem. Cycles 28 (4), 398-414. doi:10.1002/2013gb004598

Danielescu, S., MacQuarrie, K. T. B., and Faux, R. N. (2009). The integration of thermal infrared imaging, discharge measurements and numerical simulation to quantify the relative contributions of freshwater inflows to small estuaries in Atlantic Canada. Hydrol. Process 23 (20), 2847-2859. doi:10.1002/hyp.7383

Day-Lewis, F. D., White, E. A., Johnson, C. D., Lane, J. W., and Belaval, M. (2006). Continuous resistivity profiling to delineate submarine groundwater dischargeexamples and limitations. The Leading Edge 25 (6), 724-728. doi:10.1190/1. 2210056

de Graaf, I. E. M., van Beek, R. L. P. H., Gleeson, T., Moosdorf, N., Schmitz, O., Sutanudjaja, E. H., et al. (2017). A global-scale two-layer transient groundwater model: development and application to groundwater depletion. Adv. Water Resour. 102, 53-67. doi:10.1016/j.advwatres.2017.01.011

De Smedt, P., Saey, T., Lehouck, A., Stichelbaut, B., Meerschman, E., Islam, M. M., et al. (2013). Exploring the potential of multi-receiver EMI survey for geoarchaeological prospection: a 90ha dataset. Geoderma 199, 30-36. doi:10. 1016/j.geoderma.2012.07.019

Deines, P., Langmuir, D., and Harmon, R. S. (1974). Stable carbon isotope ratios and the existence of a gas phase in the evolution of carbonate ground waters. Geochim. Cosmochim. Acta 38 (7), 1147-1164. doi:10.1016/0016-7037(74) 90010-6

DeSimone, L. A., and Howes, B. L. (1996). Denitrification and nitrogen transport in a coastal aquifer receiving wastewater discharge. Environ. Sci. Technol. 30 (4), 1152-1162. doi:10.1021/es950366p
Dickson, N. E. M., Comte, J.-C., McKinley, J., and Ofterdinger, U. (2014). Coupling ground and airborne geophysical data with upscaling techniques for regional groundwater modeling of heterogeneous aquifers: case study of a sedimentary aquifer intruded by volcanic dykes in Northern Ireland. Water Resour. Res. 50 (10), 7984-8001. doi:10.1002/2014wr015320

Donis, D., Janssen, F., Liu, B., Wenzhöfer, F., Dellwig, O., Escher, P., et al. (2017). Biogeochemical impact of submarine ground water discharge on coastal surface sands of the southern Baltic Sea. Estuarine Coastal Shelf Sci. 189, 131-142. doi:10.1016/j.ecss.2017.03.003

Dulaiova, H., Camilli, R., Henderson, P. B., and Charette, M. A. (2010). Coupled radon, methane and nitrate sensors for large-scale assessment of groundwater discharge and non-point source pollution to coastal waters. J. Environ. Radioact 101 (7), 553-563. doi:10.1016/j.jenvrad.2009.12.004

Dulaiova, H., Gonneea, M. E., Henderson, P. B., and Charette, M. A. (2008). Geochemical and physical sources of radon variation in a subterranean estuary implications for groundwater radon activities in submarine groundwater discharge studies. Mar. Chem. 110 (1, 2), 120-127. doi:10.1016/j.marchem.2008.02.011

Duque, C., Jessen, S., Tirado-Conde, J., Karan, S., and Engesgaard, P. (2019). Application of stable isotopes of water to study coupled submarine groundwater discharge and nutrient delivery. Water 11 (9), 842. doi:10.3390/w11091842

Duque, C., Michael, H. A., and Wilson, A. M. (2020). The subterranean estuary: technical term, simple analogy, or source of confusion? Water Resour. Res. 56 (2), e2019WR026554. doi:10.1029/2019wr026554

Dutkiewicz, A., O'Callaghan, S., and Müller, R. D. (2016). Controls on the distribution of deep-sea sediments. Geochem. Geophys. Geosyst. 17 (8), 3075-3098. doi:10.1002/2016gc006428

Dybas, C. L. (2005). Dead zones spreading in world oceans. Bioscience 55 (7), 552-557. doi:10.1641/0006-3568(2005)055[0552:dzsiwo]2.0.co;2

Ehlert, C., Reckhardt, A., Greskowiak, J., Liguori, B. T. P., Böning, P., Paffrath, R., et al. (2016). Transformation of silicon in a sandy beach ecosystem: insights from stable silicon isotopes from fresh and saline groundwaters. Chem. Geology 440, 207-218. doi:10.1016/j.chemgeo.2016.07.015

Einsele, W. (1936). Über die Beziehungen des Eisenkreislaufs zum Phosphatkreislauf im eutrophen See. Archiv für Hydrobiologie 29, 664-686.

Encarnação, J., Leitão, F., Range, P., Piló, D., Chícharo, M. A., and Chícharo, L. (2015). Local and temporal variations in near-shore macrobenthic communities associated with submarine groundwater discharges. Mar. Ecol. 36 (4), 926-941. $10.1111 /$ maec. 12186

Erler, D. V., Santos, I. R., Zhang, Y., Tait, D. R., Befus, K. M., Hidden, A., et al. (2014). Nitrogen transformations within a tropical subterranean estuary. Mar. Chem. 164, 38-47. doi:10.1016/j.marchem.2014.05.008

Eugenio, F., Marcello, J., and Martin, J. (2015). High-resolution maps of bathymetry and benthic habitats in shallow-water environments using multispectral remote sensing imagery. IEEE Trans. Geosci. Remote Sensing 53 (7), 3539-3549. doi:10.1109/tgrs.2014.2377300

Feldens, P., Schulze, I., Papenmeier, S., Schönke, M., and Schneider von Deimling, J. (2018). Improved interpretation of marine sedimentary environments using multi-frequency multibeam backscatter data. Geosciences 8 (6), 214. doi:10. 3390/geosciences 8060214

Fisher, W. A., Moxham, R. M., Polcyn, F., and Landis, G. H. (1964). Infrared Surveys of Hawaiian Volcanoes: aerial surveys with infrared imaging radiometer depict volcanic thermal patterns and structural features. Science 146 (364), 733-742. doi:10.1126/science.146.3645.733

Fleury, P., Bakalowicz, M., and de Marsily, G. (2007). Submarine springs and coastal karst aquifers: a review. J. Hydrol. 339 (1-2), 79-92. doi:10.1016/j. jhydrol.2007.03.009

Flower, H., Rains, M., Lewis, D., Zhang, J.-Z., and Price, R. (2017). Saltwater intrusion as potential driver of phosphorus release from limestone bedrock in a coastal aquifer. Estuarine Coastal Shelf Sci. 184, 166-176. doi:10.1016/j.ecss.2016.11.013

Freeze, R. A. (1975). A stochastic-conceptual analysis of one-dimensional groundwater flow in nonuniform homogeneous media. Water Resour. Res. 11 (5), 725-741. doi:10.1029/wr011i005p00725

Fritz, P., Basharmal, G. M., Drimmie, R. J., Ibsen, J., and Qureshi, R. M. (1989). Oxygen isotope exchange between sulphate and water during bacterial reduction of sulphate. Chem. Geol. Isotope Geosci. Sect. 79 (2), 99-105. doi:10.1016/0168-9622(89)90012-2

Froelich, P. N., Klinkhammer, G. P., Bender, M. L., Luedtke, N. A., Heath, G. R., Cullen, D., et al. (1979). Early oxidation of organic matter in pelagic sediments 
of the eastern equatorial Atlantic: suboxic diagenesis. Geochim. Cosmochim. Acta 43 (7), 1075-1090. doi:10.1016/0016-7037(79)90095-4

Fulweiler, R. W., Nixon, S. W., Buckley, B. A., and Granger, S. L. (2007). Reversal of the net dinitrogen gas flux in coastal marine sediments. Nature 448 (7150), 180-182. doi:10.1038/nature05963

Garcia-Solsona, E., Masque, P., Garcia-Orellana, J., Rapaglia, J., Beck, A. J., Cochran, J. K., et al. (2008). Estimating submarine groundwater discharge around Isola La Cura, northern Venice Lagoon (Italy), by using the radium quartet. Mar. Chem. 109 (3-4), 292-306. doi:10.1016/j.marchem.2008.02.007

Gardner, W. S., McCarthy, M. J., An, S., Sobolev, D., Sell, K. S., and Brock, D. (2006). Nitrogen fixation and dissimilatory nitrate reduction to ammonium (DNRA) support nitrogen dynamics in Texas estuaries. Limnol. Oceanogr. 51 (1part2), 558-568. doi:10.4319/lo.2006.51.1_part_2.0558

Gat, J. R. (1996). Oxygen and hydrogen isotopes in the hydrologic cycle. Annu. Rev. Earth Planet. Sci. 24 (1), 225-262. doi:10.1146/annurev.earth.24.1.225

Gaudette, H. E., and Lyons, W. B. (1980). Phosphate geochemisty in nearshore carbonate sediments a suggestion of apatite formation, Durham.

Geng, X., Michael, H. A., Boufadel, M. C., Molz, F. J., Gerges, F., and Lee, K. (2020). Heterogeneity affects intertidal flow topology in coastal beach aquifers. Geophys. Res. Lett. 47 (17), e2020GL089612. doi:10.1029/2020gl089612

Gilfedder, B. S., Cartwright, I., Hofmann, H., and Frei, S. (2019). Explicit modeling of radon-222 in HydroGeoSphere during steady state and dynamic transient storage. Ground Water 57 (1), 36-47. doi:10.1111/gwat.12847

Gilfedder, B. S., Frei, S., Hofmann, H., and Cartwright, I. (2015). Groundwater discharge to wetlands driven by storm and flood events: quantification using continuous Radon-222 and electrical conductivity measurements and dynamic mass-balance modelling. Geochim. Cosmochim. Acta 165, 161-177. doi:10. 1016/j.gca.2015.05.037

Gleeson, T., Moosdorf, N., Hartmann, J., and van Beek, L. P. H. (2014). A glimpse beneath earth's surface: GLobal HYdrogeology MaPS (GLHYMPS) of permeability and porosity. Geophys. Res. Lett. 41 (11), 3891-3898. doi:10. 1002/2014gl059856

Goldscheider, N., Chen, Z., Auler, A. S., Bakalowicz, M., Broda, S., Drew, D., et al. (2020). Global distribution of carbonate rocks and karst water resources. Hydrogeol J. 28 (5), 1661-1677. doi:10.1007/s10040-020-02139-5

Gonneea, M. E., and Charette, M. A. (2014). Hydrologic controls on nutrient cycling in an unconfined coastal aquifer. Environ. Sci. Technol. 48 (24), 14178-14185. doi:10.1021/es503313t

Gonneea, M. E., Charette, M. A., Liu, Q., Herrera-Silveira, J. A., and MoralesOjeda, S. M. (2014). Trace element geochemistry of groundwater in a karst subterranean estuary (Yucatan Peninsula, Mexico). Geochimica Et Cosmochimica Acta 132, 31-49. doi:10.1016/j.gca.2014.01.037

Gonneea, M. E., Morris, P. J., Dulaiova, H., and Charette, M. A. (2008). New perspectives on radium behavior within a subterranean estuary. Mar. Chem. 109 (3-4), 250-267. doi:10.1016/j.marchem.2007.12.002

Gonneea, M. E., Mulligan, A. E., and Charette, M. A. (2013). Seasonal cycles in radium and barium within a subterranean estuary: implications for groundwater derived chemical fluxes to surface waters. Geochim. Cosmochim. Acta 119, 164-177. doi:10.1016/j.gca.2013.05.034

Goodridge, B. M., and Melack, J. M. (2014). Temporal evolution and variability of dissolved inorganic nitrogen in beach pore water revealed using radon residence times. Environ. Sci. Technol. 48 (24), 14211-14218. doi:10.1021/ es504017j

Gramling, C. M., McCorkle, D. C., Mulligan, A. E., and Woods, T. L. (2003). A carbon isotope method to quantify groundwater discharge at the land-sea interface. Limnol. Oceanogr. 48 (3), 957-970. doi:10.4319/lo.2003.48.3.0957

Greskowiak, J. (2014). Tide-induced salt-fingering flow during submarine groundwater discharge. Geophys. Res. Lett. 41 (18), 6413-6419. doi:10.1002/ $2014 \mathrm{gl} 061184$

Grünenbaum, N., Greskowiak, J., Sültenfuß, J., and Massmann, G. (2020). Groundwater flow and residence times below a meso-tidal high-energy beach: a model-based analyses of salinity patterns and $3 \mathrm{H}-3 \mathrm{He}$ groundwater ages. J. Hydrol. 587, 124948. doi:10.1016/j.jhydrol.2020.124948

Grzelak, K., Tamborski, J., Kotwicki, L., and Bokuniewicz, H. (2018). Ecostructuring of marine nematode communities by submarine groundwater discharge. Mar. Environ. Res. 136, 106-119. doi:10.1016/j. marenvres.2018.01.013
Gustafson, C., Key, K., and Evans, R. L. (2019). Aquifer systems extending far offshore on the U.S. Atlantic margin. Sci. Rep. 9 (1), 8709. doi:10.1038/s41598019-44611-7

Hajati, M. C., Sutanudjaja, E., and Moosdorf, N. (2019). Quantifying regional fresh submarine groundwater discharge with the lumped modeling approach CoCarfsgd. Water Resour. Res. 55 (7), 5321-5341. doi:10.1029/2018wr024248

Hancock, P. J., Boulton, A. J., and Humphreys, W. F. (2005). Aquifers and hyporheic zones: towards an ecological understanding of groundwater. Hydrogeol J. 13 (1), 98-111. doi:10.1007/s10040-004-0421-6

Hanshaw, B. B., and Back, W. (1980). Chemical mass-wasting of the northern yucatan Peninsula by groundwater dissolution. Geology 8 (5), 222-224. doi:10. 1130/0091-7613(1980)8<222:cmotny >2.0.co;2

Hanshaw, B. B., and Back, W. (1979). "Major geochemical processes in the evolution of carbonate-aquifer systems," in Developments in water science. Editors W. Back and D. A. Stephenson (New York, NY: Elsevier), 287-312.

Hays, R. L., and Ullman, W. J. (2007). Dissolved nutrient fluxes through a sandy estuarine beachface (Cape Henlopen, Delaware, USA): Contributions from fresh groundwater discharge, seawater recycling, and diagenesis. Estuaries Coasts 30 (4), 710-724. doi:10.1007/bf02841967

Heiss, J. W., Michael, H. A., and Koneshloo, M. (2020). Denitrification hotspots in intertidal mixing zones linked to geologic heterogeneity. Environ. Res. Lett. 15 (8), 084015. doi:10.1088/1748-9326/ab90a6

Heiss, J. W., and Michael, H. A. (2014). Saltwater-freshwater mixing dynamics in a sandy beach aquifer over tidal, spring-neap, and seasonal cycles. Water Resour. Res. 50 (8), 6747-6766. doi:10.1002/2014wr015574

Hermans, T., and Paepen, M. (2020). Combined inversion of land and marine electrical resistivity tomography for submarine groundwater discharge and saltwater intrusion characterization. Geophys. Res. Lett. 47 (3). doi:10.1029/ 2019gl085877

Hoefs, J. (2018). Stable isotope geochemistry. Göttingen, German: Springer-Nature. doi:10.1007/1978-3-319-78527-1

Hoffmann, J. J. L., von Deimling, J. S., Schroder, J. F., Schmidt, M., Held, P., Crutchley, G. J., et al. (2020). Complex eyed pockmarks and submarine groundwater discharge revealed by acoustic data and sediment cores in Eckernforde Bay, SW Baltic Sea. Geochem. Geophys. Geosystems 21 (4). doi:10.1029/2019gc008825

Hong, Y., Wu, J., Wilson, S., and Song, B. 2018). Vertical stratification of sediment microbial communities along geochemical gradients of a subterranean estuary located at the Gloucester Beach of Virginia, United States. Front. Microbiol. 9, 3343. doi: $10.3389 /$ fmicb. 2018.03343

Hovland, M., Gardner, J. V., and Judd, A. G. (2002). The significance of pockmarks to understanding fluid flow processes and geohazards. Geofluids 2 (2), 127-136. doi:10.1046/j.1468-8123.2002.00028.x

Hovland, M., and Judd, A. (1988). Seabed pockmarks and seepages: impact on geology, biology and the marine environment. Sterling House London: Graham \& Trodman. doi:10.13140/RG.2.1.1414.1286

Huerta-Diaz, M. A., and Morse, J. W. (1992). Pyritization of trace metals in anoxic marine sediments. Geochimica Et Cosmochimica Acta 56 (7), 2681-2702. doi:10.1016/0016-7037(92)90353-k

Humphreys, W. F. (2008). Rising from Down Under: developments in subterranean biodiversity in Australia from a groundwater fauna perspective. Invert. Syst. 22 (2), 85-101. doi:10.1071/is07016

Hwang, D. W., Kim, G. B., Lee, Y. W., and Yang, H. S. (2005). Estimating submarine inputs of groundwater and nutrients to a coastal bay using radium isotopes. Mar. Chem. 96 (1-2), 61-71. doi:10.1016/j.marchem.2004. 11.002

IAEA (2003). Guidelines for radioelement mapping using gamma ray spectrometry data. Vienna: International Atomic Energy Agency (IAEA).

FAOIIASA, ISRIC; ISSCAS; JRC (2009). "Harmonized World Soil Database (version 1.1)," in Rome and laxenburg. Editor I. FAO.

Jakobsson, M., O’Regan, M., Mörth, C.-M., Stranne, C., Weidner, E., Hansson, J., et al. (2020). Potential links between Baltic Sea submarine terraces and groundwater seeping. Earth Surf. Dynam. 8 (1), 1-15. doi:10.5194/esurf-8-12020

Jarsjö, J., Shibuo, Y., and Destouni, G. (2008). Spatial distribution of unmonitored inland water discharges to the sea. J. Hydrol. $348(1,2), 59-72$. doi:10.1016/j. jhydrol.2007.09.052 
Jetten, M. S., Strous, M., Van de Pas-Schoonen, K. T., Schalk, J., van Dongen, U. G., van de Graaf, A. A., et al. (1998). The anaerobic oxidation of ammonium. FEMS Microbiol. Rev. 22 (5), 421-437. doi:10.1111/j.1574-6976.1998.tb00379.x

Jiang, S., Zhang, Y. X., Jin, J., Wu, Y., Wei, Y. J., Wang, X. L., et al. (2020). Organic carbon in a seepage face of a subterranean estuary: Turnover and microbial interrelations. Sci. Total Environ., 725, 138220. doi:10.1016/j.scitotenv.2020.138220

Jiao, J., and Post, V. (2019). Coastal hydrogeology. Cambridge: Cambridge University Press

Jirka, G. H. (2004). Integral model for turbulent buoyant jets in unbounded stratified flows. Part I: Single round jet. Environ. Fluid Mech. 4 (1), 1-56. doi:10.1023/a:1025583110842

Johannes, R. (1980). The ecological significance of the submarine discharge of groundwater. Mar. Ecol. Prog. Ser. 3 (4), 365-373. doi:10.3354/meps003365

Johannesson, K. H., and Burdige, D. J. (2007). Balancing the global oceanic neodymium budget: evaluating the role of groundwater. Earth Planet. Sci. Lett. 253 (1, 2), 129-142. doi:10.1016/j.epsl.2006.10.021

Johnson, A. G., Glenn, C. R., Burnett, W. C., Peterson, R. N., and Lucey, P. G. (2008). Aerial infrared imaging reveals large nutrient-rich groundwater inputs to the ocean. Geophys. Res. Lett. 35 (15), 6. doi:10.1029/2008gl034574

Johnson, T. C., Versteeg, R. J., Day-Lewis, F. D., Major, W., and Lane, J. W. (2015). Time-lapse electrical geophysical monitoring of amendment-based biostimulation. Ground Water 53 (6), 920-932. doi:10.1111/gwat.12291

Jørgensen, B. B. (1982). Mineralization of organic-matter in the Sea Bed - the role of Sulfate reduction. Nature 296 (5858), 643-645.

Judd, A. G., and Hovland, M. (1992). The evidence of shallow gas in marine sediments. Continental Shelf Res. 12 (10), 1081-1095. doi:10.1016/02784343(92)90070-Z

Jurasinski, G., Janssen, M., Voss, M., Böttcher, M. E., Brede, M., Burchard, H., et al. (2018). Understanding the coastal ecocline: assessing sea-land interactions at non-tidal, low-ling Coasts through interdisciplinary research. Front. Mar. Sci. 5. doi:10.3389/fmars.2018.00342

Kanehisa, M., and Goto, S. (2000). KEGG: kyoto encyclopedia of genes and genomes. Nucl. Acids Res. 28 (1), 27-30. doi:10.1093/nar/28.1.27

Kazemipour, F., Launeau, P., and Méléder, V. (2012). Microphytobenthos biomass mapping using the optical model of diatom biofilms: Application to hyperspectral images of Bourgneuf Bay. Remote Sensing Environ. 127, 1-13. doi:10.1016/j.rse.2012.08.016

Kazmierczak, J., Postma, D., Müller, S., Jessen, S., Nilsson, B., Czekaj, J., et al. (2020). Groundwater-controlled phosphorus release and transport from sandy aquifer into lake. Limnol. Oceanogr. 65 (9), 2188-2204. doi:10.1002/lno.11447

Keating, K., and Knight, R. (2007). A laboratory study to determine the effect of iron oxides on proton NMR measurements. Geophysics 72 (1), E27-E32. doi:10. 1190/1.2399445

Kelly, J. L., Glenn, C. R., and Lucey, P. G. (2013). High-resolution aerial infrared mapping of groundwater discharge to the coastal ocean. Limnol. Oceanogr. Methods 11, 262-277. doi:10.4319/lom.2013.11.262

Kim, G., Kim, J.-S., and Hwang, D.-W. (2011). Submarine groundwater discharge from oceanic islands standing in oligotrophic oceans: Implications for global biological production and organic carbon fluxes. Limnol. Oceanogr. 56 (2), 673-682. doi:10.4319/lo.2011.56.2.0673

Kim, J., and Kim, G. (2017). Inputs of humic fluorescent dissolved organic matter via submarine groundwater discharge to coastal waters off a volcanic island (Jeju, Korea). Sci. Rep. 7, 7921. doi:10.1038/s41598-017-08518-5

Kim, K. H., Heiss, J. W., Geng, X., and Michael, H. A. (2020). Modeling hydrologic controls on particulate organic carbon contributions to beach aquifer biogeochemical reactivity. Water Resour. Res. 56 (10), e2020WR027306. doi:10.1029/2020wr027306

Kim, K. H., Heiss, J. W., Michael, H. A., Cai, W.-J., Laattoe, T., Post, V. E. A., et al. (2017). Spatial patterns of groundwater biogeochemical reactivity in an intertidal beach aquifer. J. Geophys. Res. Biogeosci. 122 (10), 2548-2562. doi:10.1002/2017jg003943

Kim, K. H., Michael, H. A., Field, E. K., and Ullman, W. J. (2019). Hydrologic shifts create complex transient distributions of particulate organic carbon and biogeochemical responses in beach aquifers. J. Geophys. Res. Biogeosci. 124 (10), 3024-3038. doi:10.1029/2019jg005114

Kim, T.-H., Kwon, E., Kim, I., Lee, S.-A., and Kim, G. (2013). Dissolved organic matter in the subterranean estuary of a volcanic island, Jeju: Importance of dissolved organic nitrogen fluxes to the ocean. J. Sea Res. 78, 18-24. doi:10. 1016/j.seares.2012.12.009

Kim, T.-H., Waska, H., Kwon, E., Suryaputra, I. G. N., and Kim, G. (2012). Production, degradation, and flux of dissolved organic matter in the subterranean estuary of a large tidal flat. Mar. Chem. 142-144, 1-10. doi:10. 1016/j.marchem.2012.08.002

Kipp, L. E., Henderson, P. B., Wang, Z. A., and Charette, M. A. (2020). Deltaic and estuarine controls on mackenzie river solute fluxes to the arctic Ocean. Estuaries and coasts. 42, 1992-2014. doi:10.1007/s12237-020-00739-8

Kirsch, R. (2006). Groundwater Geophysics-a tool for hydrogeology. Flintbek, Germany, Springer.

Klemas, V. V. (2016). Remote Sensing of Submerged Aquatic VegetationSeafloor mapping along continental shelves, Res. Tech. Visualizing Benthic Environments. 13, 125-140. doi:10.1007/978-3-319

Knee, K. L., and Paytan, A. (2011). "4.08 - Submarine groundwater discharge: a source of nutrients, metals, and pollutants to the coastal ocean", in Treatise on estuarine and coastal science. Waltham: Academic Press, 205-233.

Kotwicki, L., Grzelak, K., Czub, M., Dellwig, O., Gentz, T., Szymczycha, B., et al. (2014). Submarine groundwater discharge to the Baltic coastal zone: Impacts on the meiofaunal community. J. Mar. Syst. 129, 118-126. doi:10.1016/j.jmarsys. 2013.06.009

Kowalski, N., Dellwig, O., Beck, M., Grunwald, M., Dürselen, C.-D., Badewien, T. H., et al. (2012). A comparative study of manganese dynamics in the water column and sediments of intertidal systems of the North Sea. Estuarine Coast. Shelf Sci. 100, 3-17. doi:10.1016/j.ecss.2011.03.011

Kroeger, K. D., and Charette, M. A. (2008). Nitrogen biogeochemistry of submarine groundwater discharge. Limnol. Oceanogr. 53 (3), 1025. doi:10. 4319/lo.2008.53.3.1025

Kwon, E. Y., Kim, G., Primeau, F., Moore, W. S., Cho, H.-M., DeVries, T., et al. (2014). Global estimate of submarine groundwater discharge based on an observationally constrained radium isotope model. Geophys. Res. Lett. 41 (23), 2014GL061574. doi:10.1002/2014gl061574

Lagouarde, J.-P., Bhattacharya, B. K., Crebassol, P., Gamet, P., Babu, S. S., Boulet, G., et al. (2018). The Indian-French Trishna mission: Earth observation in the thermal infrared with high spatio-temporal resolution. IGARSS 2018-2018 IEEE international geoscience and remote sensing symposium. IEEE, 4078-4081.

Langguth, H. R., and Voigt, R. (2004). Hydrogeologische methoden. Berlin, Heidelberg: Springer, 1014.

Laruelle, G. G., Dürr, H. H., Slomp, C. P., and Borges, A. V. (2010). Evaluation of sinks and sources of CO2in the global coastal ocean using a spatially-explicit typology of estuaries and continental shelves. Geophys. Res. Lett. 37 (15), doi:10. 1029/2010gl043691

Lausch, A., Pause, M., Merbach, I., Zacharias, S., Doktor, D., Volk, M., et al. (2013). A new multiscale approach for monitoring vegetation using remote sensingbased indicators in laboratory, field, and landscape. Environ. Monit. Assess. 185 (2), 1215-1235. doi:10.1007/s10661-012-2627-8

Lebbe, L. (1981). The subterranean flow of fresh and salt water underneath the western Belgian beach. Uppsala, Sweden: Proceedings of the 7th Salt Water Intrusion Meeting, 193-219.

Lecher, A. L., Chien, C.-T., and Paytan, A. (2016a). Submarine groundwater discharge as a source of nutrients to the North Pacific and Arctic coastal ocean. Mar. Chem. 186, 167-177. doi:10.1016/j.marchem.2016.09.008

Lecher, A. L., Kessler, J., Sparrow, K., Garcia-Tigreros Kodovska, F., Dimova, N. Murray, J., et al. (2016b). Methane transport through submarine groundwater discharge to the North Pacific and Arctic Ocean at two Alaskan sites. Limnol. Oceanogr. 61 (S1), S344-S355. doi:10.1002/lno.10118

Lecher, A., and Mackey, K. (2018). Synthesizing the effects of submarine groundwater discharge on Marine Biota. Hydrology 5 (4), 60. doi:10.3390/ hydrology5040060

Lee, E., Shin, D., Hyun, S. P., Ko, K.-S., Moon, H. S., Koh, D.-C., et al. (2017). Periodic change in coastal microbial community structure associated with submarine groundwater discharge and tidal fluctuation. Limnol. Oceanogr. 62 (2), 437-451. doi:10.1002/lno.10433

Leitão, F., Encarnação, J., Range, P., Schmelz, R. M., Teodósio, M. A., and Chícharo, L. (2015). Submarine groundwater discharges create unique benthic 
communities in a coastal sandy marine environment. Estuarine Coastal Shelf Sci. 163, 93-98. doi:10.1016/j.ecss.2015.06.007

Lewandowski, J., Meinikmann, K., Nützmann, G., and Rosenberry, D. O. (2015). Groundwater - the disregarded component in lake water and nutrient budgets. Part 2: effects of groundwater on nutrients. Hydrol. Process. 29 (13), 2922-2955. doi:10.1002/hyp.10384

Linkhorst, A., Dittmar, T., and Waska, H. (2017). Molecular fractionation of dissolved organic matter in a shallow subterranean estuary: the role of the iron curtain. Environ. Sci. Technol. 51 (3), 1312-1320. doi:10.1021/acs.est. 6b03608

Lipka, M., Böttcher, M. E., Wu, Z., Sültenfuß, J., Jenner, A.-K., Westphal, J., et al. (2018). Ferruginous groundwaters as a source of P, Fe, and DIC for coastal waters of the southern Baltic Sea: (Isotope) hydrobiogeochemistry and the role of an iron curtain. E3s Web Conf. 54, 00019. doi:10.1051/e3sconf/ 20185400019

Liu, Q., Charette, M. A., Breier, C. F., Henderson, P. B., McCorkle, D. C., Martin, W., et al. (2017). Carbonate system biogeochemistry in a subterranean estuary Waquoit Bay, USA. Geochim. Cosmochim. Acta 203, 422-439. doi:10.1016/j. gca.2017.01.041

Liu, Q., Dai, M., Chen, W., Huh, C.-A., Wang, G., Li, Q., et al. (2012). How significant is submarine groundwater discharge and its associated dissolved inorganic carbon in a river-dominated shelf system? Biogeosciences 9 (5), 1777-1795. doi:10.5194/bg-9-1777-2012

Lopez, C. V., Murgulet, D., and Santos, I. R. (2020). Radioactive and stable isotope measurements reveal saline submarine groundwater discharge in a semiarid estuary. J. Hydrol. 590, 125395. doi:10.1016/j.jhydrol.2020.125395

Loveless, A. M., and Oldham, C. E. (2010). Natural attenuation of nitrogen in groundwater discharging through a sandy beach. Biogeochemistry 98 (1-3), 75-87. doi:10.1007/s10533-009-9377-x

Luijendijk, E., Gleeson, T., and Moosdorf, N. (2020). Fresh groundwater discharge insignificant for the world's oceans but important for coastal ecosystems. Nat. Commun. 11 (1), 1260. doi:10.1038/s41467-020-15064-8

Luther, G. W., Church, T. M., and Powell, D. (1991). Sulfur speciation and sulfide oxidation in the water column of the Black Sea. Deep Sea Res. A. Oceanographic Res. Pap. 38, S1121-S1137. doi:10.1016/s0198-0149(10)80027-5

Macklin, P. A., Suryaputra, I. G. N. A., Maher, D. T., Murdiyarso, D., and Santos, I. R. (2019). Drivers of CO2 along a mangrove-seagrass transect in a tropical bay: Delayed groundwater seepage and seagrass uptake. Continental Shelf Res. 172, 57-67. doi:10.1016/j.csr.2018.10.008

Mallast, U., Gloaguen, R., Friesen, J., Rödiger, T., Geyer, S., Merz, R., et al. (2014). How to identify groundwater-caused thermal anomalies in lakes based on multi-temporal satellite data in semi-arid regions. Hydrol. Earth Syst. Sci. 18 (7), 2773-2787. doi:10.5194/hess-18-2773-2014

Mallast, U., and Siebert, C. (2019). Combining continuous spatial and temporal scales for SGD investigations using UAV-based thermal infrared measurements. Hydrol. Earth Syst. Sci. 23 (3), 1375-1392. doi:10.5194/hess23-1375-2019

Manheim, F. T., Krantz, D. E., and Bratton, J. F. (2004). Studying ground water under delmarva coastal bays using electrical resistivity. Ground Water 42 (7), 1052-1068. doi:10.1111/j.1745-6584.2004.tb02643.x

Mansoor, N., and Slater, L. (2007). On the relationship between iron concentration and induced polarization in marsh soils. Geophysics 72 (1), A1-A5. doi:10.1190/ 1.2374853

Marchant, H. K., Holtappels, M., Lavik, G., Ahmerkamp, S., Winter, C., and Kuypers, M. M. M. (2016). Coupled nitrification-denitrification leads to extensive $\mathrm{N}$ loss in subtidal permeable sediments. Limnol. Oceanogr. 61 (3), 1033-1048. doi:10.1002/lno.10271

Mayfield, K. K., Eisenhauer, A., Santiago Ramos, D. P., Higgins, J. A., Horner, T. J., Auro, M., et al. (2021). Groundwater discharge impacts marine isotope budgets of Li, Mg, Ca, Sr, and Ba. Nat. Commun. 12 (1), 148. doi:10.1038/s41467-02020248-3

McGrath, G. S., Paik, K., and Hinz, C. (2012). Microtopography alters selforganized vegetation patterns in water-limited ecosystems. J. Geophys. Research-Biogeosciences 117. doi:10.1029/2011jg001870

Meister, P., Liu, B., Khalili, A., Böttcher, M. E., and Jørgensen, B. B. (2019). Factors controlling the carbon isotope composition of dissolved inorganic carbon and methane in marine porewater: An evaluation by reaction-transport modelling. J. Mar. Syst. 200, 103227. doi:10.1016/j.jmarsys.2019.103227
Mejías, M., Ballesteros, B. J., Antón-Pacheco, C., Domínguez, J. A., GarciaOrellana, J., Garcia-Solsona, E., et al. (2012). Methodological study of submarine groundwater discharge from a karstic aquifer in the Western Mediterranean Sea. J. Hydrol. 464-465, 27-40. doi:10.1016/j.jhydrol.2012. 06.020

Meyer, D., Prien, R. D., Dellwig, O., Waniek, J. J., and Schulz-Bull, D. E. (2014). Electrode measurements of the oxidation reduction potential in the Gotland Deep using a moored profiling instrumentation. Estuarine Coastal Shelf Sci. 141, 26-36. doi:10.1016/j.ecss.2014.02.001

Michael, H. A., Mulligan, A. E., and Harvey, C. F. (2005). Seasonal oscillations in water exchange between aquifers and the coastal ocean. Nature 436 (7054), 1145-1148. doi:10.1038/nature03935

Migné, A., Ouisse, V., Hubas, C., and Davoult, D. (2011). Freshwater seepages and ephemeral macroalgae proliferation in an intertidal bay: II. Effect on benthic biomass and metabolism. Estuarine, Coastal Shelf Sci. 92 (1), 161-168. doi:10. 1016/j.ecss.2010.12.023

Miller, D. C., and Ullman, W. J. (2004). Ecological consequences of ground water discharge to Delaware Bay, United States. Ground Water 42 (7), 959-970. doi:10.1111/j.1745-6584.2004.tb02635.x

Missiaen, T., Murphy, S., Loncke, L., and Henriet, J.-P. (2002). Very highresolution seismic mapping of shallow gas in the Belgian coastal zone. Continental Shelf Res. 22 (16), 2291-2301. doi:10.1016/s0278-4343(02) 00056-0

Mollenhauer, H., Kasner, M., Haase, P., Peterseil, J., Wohner, C., Frenzel, M., et al. (2018). Long-term environmental monitoring infrastructures in Europe: observations, measurements, scales, and socio-ecological representativeness. Sci. Total Environ. 624, 968-978. doi:10.1016/j.scitotenv.2017.12.095

Montiel, D., Lamore, A. F., Stewart, J., Lambert, W. J., Honeck, J., Lu, Y., et al. (2019). Natural groundwater nutrient fluxes exceed anthropogenic inputs in an ecologically impacted estuary: lessons learned from Mobile Bay, Alabama. Biogeochemistry 145 (1), 1-33. doi:10.1007/s10533-019-00587-0

Moore, W. S., Beck, M., Riedel, T., Rutgers van der Loeff, M., Dellwig, O., Shaw, T. J., et al. (2011). Radium-based pore water fluxes of silica, alkalinity, manganese, DOC, and uranium: A decade of studies in the German Wadden Sea. Geochim. Cosmochim. Acta 75 (21), 6535-6555. doi:10.1016/j.gca.2011.08.037

Moore, W. S. (2000). Determining coastal mixing rates using radium isotopes. Continental Shelf Res. 20 (15), 1993-2007. doi:10.1016/s0278-4343(00)00054-6

Moore, W. S. (1996). Large groundwater inputs to coastal waters revealed by $226 \mathrm{Ra}$ enrichments. Nature 380 (6575), 612-614. doi:10.1038/380612a0

Moore, W. S., Sarmiento, J. L., and Key, R. M. (2008). Submarine groundwater discharge revealed by 228Ra distribution in the upper Atlantic Ocean. Nat. Geosci. 1 (5), 309-311. doi:10.1038/ngeo183

Moore, W. S. (2003). Sources and fluxes of submarine groundwater discharge delineated by radium isotopes. Biogeochemistry $66(1,2), 75-93$. doi:10.1023/b: biog.0000006065.77764.a0

Moore, W. S. (1999). The subterranean estuary: a reaction zone of ground water and sea water. Mar. Chem. 65 (1, 2), 111-125. doi:10.1016/s0304-4203(99) 00014-6

Moosdorf, N., Hartmann, J., and Dürr, H. H. (2010). Lithological composition of the North American continent and implications of lithological map resolution for dissolved silica flux modeling. Geochem. Geophys. Geosyst. 11, . doi:10.1029/ $2010 \mathrm{gc} 003259$

Morrow, F. J., Ingham, M. R., and McConchie, J. A. (2010). Monitoring of tidal influences on the saline interface using resistivity traversing and cross-borehole resistivity tomography. J. Hydrol. 389 (1-2), 69-77. doi:10.1016/j.jhydrol.2010. 05.022

Mosher, D. C., and Simpkin, P. G. (1999). Environmental marine Geoscience 1. Status and trends of marine high-resolution seismic reflection profiling: Data acquistion. Geosci. Can. 26, 174-188.

Müller, H. (2010). Characterization of marine near-surface sediments by electromagnetic profiling. Bremen: University of Bremen.

Müller, H., von Dobeneck, T., Nehmiz, W., and Hamer, K. (2011). Near-surface electromagnetic, rock magnetic, and geochemical fingerprinting of submarine freshwater seepage at Eckernförde Bay (SW Baltic Sea). Geo-mar Lett. 31 (2), 123-140. doi:10.1007/s00367-010-0220-0

Müller-Petke, M., and Yaramanci, U. (2015). "11.13 - Tools and Techniques: Nuclear Magnetic Resonance," in Treatise on geophysics. Editor G. Schubert. Second Edition (Oxford: Elsevier), 419-445. 
Musat, N., Werner, U., Knittel, K., Kolb, S., Dodenhof, T., van Beusekom, J. E., et al. (2006). Microbial community structure of sandy intertidal sediments in the North Sea, Sylt-Rømø Basin, Wadden Sea. Syst. Appl. Microbiol. 29 (4), 333-348. doi:10.1016/j.syapm.2005.12.006

Mylroie, J. E., and Carew, J. L. (1990). The Flank Margin model for dissolution cave development in carbonate platforms. Earth Surf. Process. Landforms 15 (5), 413-424. doi:10.1002/esp.3290150505

Nakada, S., Yasumoto, J., Taniguchi, M., and Ishitobi, T. (2011). Submarine groundwater discharge and seawater circulation in a subterranean estuary beneath a tidal flat. Hydrol. Process 25 (17), 2755-2763. doi:10.1002/hyp.8016

Nick, H., Raoof, A., Centler, F., Thullner, M., and Regnier, P. (2013). Reactive dispersive contaminant transport in coastal aquifers: numerical simulation of a reactive Henry problem. J. Contam. Hydrol. 145, 90-104. doi:10.1016/j.jconhyd. 2012.12.005

Nowicki, B. L., Requintina, E., Van Keuren, D., and Portnoy, J. (1999). The role of sediment denitrification in reducing groundwater-derived nitrate inputs to Nauset Marsh Estuary, Cape Cod, Massachusetts. Estuaries 22 (2), 245-259. doi:10.2307/1352981

O'Connor, A. E., Krask, J. L., Canuel, E. A., and Beck, A. J. (2018). Seasonality of major redox constituents in a shallow subterranean estuary. Geochim. Cosmochim. Acta 224, 344-361. doi:10.1016/j.gca.2017.10.013

O’Reilly, C., Santos, I. R., Cyronak, T., McMahon, A., and Maher, D. T. (2015). Nitrous oxide and methane dynamics in a coral reef lagoon driven by pore water exchange: Insights from automated high-frequency observations. Geophys. Res. Lett. 42 (8), 2885-2892. doi:10.1002/2015gl063126

Oehler, T., Bakti, H., Lubis, R. F., Purwoarminta, A., Delinom, R., and Moosdorf, N. (2019a). Nutrient dynamics in submarine groundwater discharge through a coral reef (western Lombok, Indonesia). Limnol. Oceanogr. 64 (6), 2646-2661. doi:10.1002/lno.11240

Oehler, T., Eiche, E., Putra, D., Adyasari, D., Hennig, H., Mallast, U., et al. (2018). Seasonal variability of land-ocean groundwater nutrient fluxes from a tropical karstic region (southern Java, Indonesia). J. Hydrol. 565, 662-671. doi:10.1016/j. jhydrol.2018.08.077

Oehler, T., Mogollón, J. M., Moosdorf, N., Winkler, A., Kopf, A., and Pichler, T. (2017). Submarine groundwater discharge within a landslide scar at the French Mediterranean coast. Estuarine Coastal Shelf Sci. 198, 128-137. doi:10.1016/j. ecss.2017.09.006

Oehler, T., Tamborski, J., Rahman, S., Moosdorf, N., Ahrens, J., Mori, C., et al. (2019b). DSi as a Tracer for Submarine Groundwater Discharge. Front. Mar. Sci. 6 (563). doi:10.3389/fmars.2019.00563

Paffrath, R., Pahnke, K., Behrens, M. K., Reckhardt, A., Ehlert, C., Schnetger, B., et al. (2020). Rare earth element behavior in a sandy subterranean estuary of the southern North Sea. Front. Mar. Sci. doi:10.3389/fmars.2020.00424

Pain, A. J., Martin, J. B., and Young, C. R. (2019). Sources and sinks of $\mathrm{CO}_{2}$ and $\mathrm{CH}_{4}$ in siliciclastic subterranean estuaries. Limnol. Oceanogr. 64 (4), 1500-1514. doi:10.1002/lno.11131

Pain, A. J., Martin, J. B., Young, C. R., Valle-Levinson, A., and Mariño-Tapia, I. (2020). Carbon and phosphorus processing in a carbonate karst aquifer and delivery to the coastal ocean. Geochim. et Cosmochim. Acta 269, 484-495. doi:10.1016/j.gca.2019.10.040

Papenmeier, S., Darr, A., Feldens, P., and Michaelis, R. (2020). Hydroacoustic mapping of geogenic hard substrates: challenges and review of German approaches. Geosciences 10 (3), 100. doi:10.3390/geosciences10030100

Petersen, W., Schroeder, F., and Bockelmann, F.-D. (2011). FerryBox - Application of continuous water quality observations along transects in the North Sea. Ocean Dyn. 61 (10), 1541-1554. doi:10.1007/s10236-011-0445-0

Pisternick, T., Lilkendey, J., Audit-Manna, A., Dumur Neelayya, D., Neehaul, Y., and Moosdorf, N. (2020). Submarine groundwater springs are characterized by distinct fish communities. Mar. Ecol., 41 (5), e12610. doi:10.1111/maec.12610

Post, V. E. A., Houben, G. J., Stoeckl, L., and Sültenfuß, J. (2019). Behaviour of tritium and tritiogenic helium in freshwater lens groundwater systems: insights from Langeoog island. Germany: Geofluids, 1494326

Post, V. E. A., Vandenbohede, A., Werner, A. D., and Maimun, M. D. (2013). Groundwater ages in coastal aquifers. Adv. Water Resour. 57, 1-11. doi:10.1016/ j.advwatres.2013.03.011

Povinec, P. P., Burnett, W. C., Beck, A., Bokuniewicz, H., Charette, M., Gonneea, M. E., et al. (2012). Isotopic, geophysical and biogeochemical investigation of submarine groundwater discharge: IAEA-UNESCO intercomparison exercise at Mauritius Island. J. Environ. Radioact 104, 24-45. doi:10.1016/j.jenvrad.2011. 09.009

Prandle, D., (2009). Estuaries: dynamics, mixing, sedimentation, and morphology. Cambridge: Cambridge University Press, ix, 236

Price, R. M., Savabi, M. R., Jolicoeur, J. L., and Roy, S. (2010). Adsorption and desorption of phosphate on limestone in experiments simulating seawater intrusion. Appl. Geochem. 25 (7), 1085-1091. doi:10.1016/j.apgeochem.2010. 04.013

Prieto, C., and Destouni, G. (2011). Is submarine groundwater discharge predictable?. Geophys. Res. Lett. 38. doi:10.1029/2010gl045621

Prouty, N. G., Cohen, A., Yates, K. K., Storlazzi, C. D., Swarzenski, P. W., and White, D. (2017a). Vulnerability of Coral Reefs to Bioerosion From Land-Based Sources of Pollution. J. Geophys. Res.122 (12), 9319-9331. doi:10.1002/ 2017JC013264

Prouty, N. G., Swarzenski, P. W., Fackrell, J. K., Johannesson, K., and Palmore, C. D. (2017b). Groundwater-derived nutrient and trace element transport to a nearshore Kona coral ecosystem: Experimental mixing model results. J. Hydrol. Reg. Stud. 11, 166-177. doi:10.1016/j.ejrh.2015.12.058

Rahman, S., Tamborski, J. J., Charette, M. A., and Cochran, J. K. (2019). Dissolved silica in the subterranean estuary and the impact of submarine groundwater discharge on the global marine silica budget. Mar. Chem. 208, 29-42. doi:10. 1016/j.marchem.2018.11.006

Rakhimbekova, S., O'Carroll, D. M., Andersen, M. S., Wu, M. Z., and Robinson, C. E. (2018). Effect of Transient Wave Forcing on the Behavior of Arsenic in a Nearshore Aquifer. Environ. Sci. Technol. 52 (21), 12338-12348. doi:10.1021/ acs.est.8b03659

Rao, A. M. F., and Charette, M. A. (2012). Benthic nitrogen fixation in an eutrophic estuary affected by groundwater discharge. J. Coast. Res. 280 (2), 477-485. doi:10.2112/jcoastres-d-11-00057.1

Rasmussen, B., and Josefson, A. B. (2002). Consistent estimates for the residence time of micro-tidal estuaries. Estuarine Coastal Shelf Sci. 54 (1), 65-73. doi:10. 1006/ecss.2001.0836

Reckhardt, A., Beck, M., Greskowiak, J., Schnetger, B., Böttcher, M. E., Gehre, M., et al. (2017). Cycling of redox-sensitive elements in a sandy subterranean estuary of the southern North Sea. Mar. Chem. 188, 6-17. doi:10.1016/j. marchem.2016.11.003

Rickard, D. (1997). Kinetics of pyrite formation by the H2S oxidation of iron (II) monosulfide in aqueous solutions between 25 and $125^{\circ} \mathrm{C}$ : The rate equation. Geochim. Cosmochim. Acta 61 (1), 115-134. doi:10.1016/s0016-7037(96) 00321-3

Riechelmann, S., Mavromatis, V., Buhl, D., Dietzel, M., and Immenhauser, A. (2020). Controls on formation and alteration of early diagenetic dolomite: A multi-proxy $\delta 44 / 40 \mathrm{Ca}, \delta 26 \mathrm{Mg}, \delta 18 \mathrm{O}$ and $\delta 13 \mathrm{C}$ approach. Geochim. Cosmochim. Acta 283, 167-183. doi:10.1016/j.gca.2020.06.010

Robinson, C., Brovelli, A., Barry, D. A., and Li, L. (2009). Tidal influence on BTEX biodegradation in sandy coastal aquifers. Adv. Water Resour. 32 (1), 16-28. doi:10.1016/j.advwatres.2008.09.008

Robinson, C. E., Xin, P., Santos, I. R., Charette, M. A., Li, L., and Barry, D. A. (2017). Groundwater dynamics in subterranean estuaries of coastal unconfined aquifers: Controls on submarine groundwater discharge and chemical inputs to the ocean. Adv. Water Resour.

Robinson, C. E., Xin, P., Santos, I. R., Charette, M. A., Li, L., and Barry, D. A. (2018). Groundwater dynamics in subterranean estuaries of coastal unconfined aquifers: Controls on submarine groundwater discharge and chemical inputs to the ocean. Adv. Water Resour. 115, 315-331. doi:10.1016/j.advwatres.2017. 10.041

Robinson, C., Gibbes, B., and Li, L. (2006). Driving mechanisms for groundwater flow and salt transport in a subterranean estuary. Geophys. Res. Lett. 33 (3). doi:10.1029/2005gl025247

Robinson, C., Li, L., and Barry, D. A. (2007). Effect of tidal forcing on a subterranean estuary. Adv. Water Resour. 30 (4), 851-865. doi:10.1016/j. advwatres.2006.07.006

Robinson, C., Xin, P., Li, L., and Barry, D. A. (2014). Groundwater flow and salt transport in a subterranean estuary driven by intensified wave conditions. Water Resour. Res. 50 (1), 165-181. doi:10.1002/2013wr013813

Rocha, C., Robinson, C. E., Santos, I. R., Waska, H., Michael, H. A., and Bokuniewicz, H. J. (2021). A place for subterranean estuaries in the coastal zone. Estuarine. Coastal Shelf Sci. 250, 107167. doi:10.1016/j.ecss.2021.107167 
Rocha, C., Veiga-Pires, C., Scholten, J., Knoeller, K., Gröcke, D. R., Carvalho, L., et al. (2016). Assessing land-ocean connectivity via submarine groundwater discharge (SGD) in the Ria Formosa Lagoon (Portugal): combining radon measurements and stable isotope hydrology. Hydrol. Earth Syst. Sci. 20 (8), 3077-3098. doi:10.5194/hess-20-3077-2016

Rodellas, V., Garcia-Orellana, J., Masqué, P., Feldman, M., and Weinstein, Y. (2015). Submarine groundwater discharge as a major source of nutrients to the Mediterranean Sea. Proc. Natl. Acad. Sci. USA 112 (13), 3926-3930. doi:10. 1073/pnas.1419049112

Rodellas, V., Stieglitz, T. C., Tamborski, J. J., van Beek, P., Andrisoa, A., and Cook, P. G. (2021). Conceptual uncertainties in groundwater and porewater fluxes estimated by radon and radium mass balances. Limnol. Oceanogr. 11, 676. doi:10.1002/lno.11678

Rogers, D. R., and Casciotti, K. L. (2010). Abundance and diversity of archaeal ammonia oxidizers in a coastal groundwater system. Appl. Environ. Microbiol. 76 (24), 7938-7948. doi:10.1128/AEM.02056-09

Röper, T., Kröger, K. F., Meyer, H., Sültenfuss, J., Greskowiak, J., and Massmann, G. (2012). Groundwater ages, recharge conditions and hydrochemical evolution of a barrier island freshwater lens (Spiekeroog, Northern Germany). J. Hydrol. 454-455, 173-186. doi:10.1016/j.jhydrol.2012.06.011

Roseen, R. M. (2002). Quantifying groundwater discharge using thermal imagery and conventional groundwater exploration techniques for estimating the nitrogen loading to a meso-scale inland estuary. Durham.

Roy, M., Martin, J. B., Cable, J. E., and Smith, C. G. (2013). Variations of iron flux and organic carbon remineralization in a subterranean estuary caused by interannual variations in recharge. Geochim. Cosmochim. Acta 103, 301-315. doi:10. 1016/j.gca.2012.10.055

Roy, M., Martin, J. B., Cherrier, J., Cable, J. E., and Smith, C. G. (2010). Influence of sea level rise on iron diagenesis in an east Florida subterranean estuary. Geochim. Cosmochim. Acta 74 (19), 5560-5573. doi:10.1016/j.gca.2010.07.007

Roy, M., Martin, J. B., Smith, C. G., and Cable, J. E. (2011). Reactive-transport modeling of iron diagenesis and associated organic carbon remineralization in a Florida (USA) subterranean estuary. Earth Planet. Sci. Lett. 304 (1, 2), 191-201. doi:10.1016/j.epsl.2011.02.002

Rullkötter, J. (2009). The back-barrier tidal flats in the southern North Sea-a multidisciplinary approach to reveal the main driving forces shaping the system. Ocean Dyn. 59 (2), 157-165. doi:10.1007/s10236-009-0197-2

Sáenz, J. P., Hopmans, E. C., Rogers, D., Henderson, P. B., Charette, M. A., Schouten, S., et al. (2012). Distribution of anaerobic ammonia-oxidizing bacteria in a subterranean estuary. Mar. Chem. 136, 137, 7-13. doi:10.1016/ j.marchem.2012.04.004

Salt, D. E., Blaylock, M., Kumar, N. P., Dushenkov, V., Ensley, B. D., Chet, I., et al. (1995). Phytoremediation: a novel strategy for the removal of toxic metals from the environment using plants. Biotechnology (NY) 13 (5), 468-474. doi:10.1038/ nbt0595-468

Sánchez-Úbeda, J. P., Manuel, L.-C., Calvache, M., Purtschert, R., Engesgaard, P., Martín-Montañés, C., et al. (2018). Groundwater age dating in motril-salobreña coastal aquifer with environmental tracers $3 \mathrm{H} / 3 \mathrm{He}, 4 \mathrm{He}, 85 \mathrm{Kr}$, and 39Ar), Spain. Granada. $\delta 18 \mathrm{O} / \delta 2 \mathrm{H}, 287-295$.

Sanders, C. J., Santos, I. R., Barcellos, R., and Silva Filho, E. V. (2012). Elevated concentrations of dissolved $\mathrm{Ba}, \mathrm{Fe}$ and $\mathrm{Mn}$ in a mangrove subterranean estuary: Consequence of sea level rise?. Continental Shelf Res. 43, 86-94. doi:10.1016/j. csr.2012.04.015

Santoro, A. E., Boehm, A. B., and Francis, C. A. (2006). Denitrifier community composition along a nitrate and salinity gradient in a coastal aquifer. Appl. Environ. Microbiol. 72 (3), 2102-2109. doi:10.1128/AEM.72.3.2102-2109. 2006

Santoro, A. E., Francis, C. A., de Sieyes, N. R., and Boehm, A. B. (2008). Shifts in the relative abundance of ammonia-oxidizing bacteria and archaea across physicochemical gradients in a subterranean estuary. Environ. Microbiol. 10 (4), 1068-1079. doi:10.1111/j.1462-2920.2007.01547.x

Santoro, A. E. (2010). Microbial nitrogen cycling at the saltwater-freshwater interface. Hydrogeol J. 18 (1), 187-202. doi:10.1007/s10040-009-0526-z

Santos, I. R., Beck, M., Brumsack, H.-J., Maher, D. T., Dittmar, T., Waska, H., et al. (2015). Porewater exchange as a driver of carbon dynamics across a terrestrialmarine transect: Insights from coupled 222Rn and pCO2 observations in the German Wadden Sea. Mar. Chem. 171, 10-20. doi:10.1016/j.marchem.2015. 02.005
Santos, I. R., Burnett, W. C., Chanton, J., Dimova, N., and Peterson, R. N. (2009a). Land or ocean?: Assessing the driving forces of submarine groundwater discharge at a coastal site in the Gulf of Mexico. J. Geophys. Res.-Oceans 114, 11. doi:10.1029/2008jc005038

Santos, I. R., Burnett, W. C., Dittmar, T., Suryaputra, I. G. N. A., and Chanton, J. (2009b). Tidal pumping drives nutrient and dissolved organic matter dynamics in a Gulf of Mexico subterranean estuary. Geochim. Cosmochim. Acta 73 (5), 1325-1339. doi:10.1016/j.gca.2008.11.029

Santos, I. R., Dimova, N., Peterson, R. N., Mwashote, B., Chanton, J., and Burnett, W. C. (2009c). Extended time series measurements of submarine groundwater discharge tracers $(222 \mathrm{Rn}$ and $\mathrm{CH} 4)$ at a coastal site in Florida. Mar. Chem. 113 (1, 2), 137-147. doi:10.1016/j.marchem.2009.01.009

Santos, I. R., Eyre, B. D., and Huettel, M. (2012). The driving forces of porewater and groundwater flow in permeable coastal sediments: a review. Estuarine Coastal Shelf Sci. 98, 1-15. doi:10.1016/j.ecss.2011.10.024

Santos, I. R. S., Burnett, W. C., Chanton, J., Mwashote, B., Suryaputra, I. G. N. A., and Dittmar, T. (2008). Nutrient biogeochemistry in a Gulf of Mexico subterranean estuary and groundwater-derived fluxes to the coastal ocean. Limnol. Oceanogr. 53 (2), 705. doi:10.4319/lo.2008.53.2.0705

Sawyer, A. H., David, C. H., and Famiglietti, J. S. (2016). Continental patterns of submarine groundwater discharge reveal coastal vulnerabilities. Science 353 (6300), 705-707. doi:10.1126/science.aag1058

Sayre, R., Noble, S., Hamann, S., Smith, R., Wright, D., Breyer, S., et al. (2018). A new 30 meter resolution global shoreline vector and associated global islands database for the development of standardized ecological coastal units. J. Oper. Oceanogr., 12, 1-10. doi:10.1080/1755876X.2018.1529714

Schlüter, M., Sauter, E. J., Andersen, C. E., Dahlgaard, H., and Dando, P. R. (2004). Spatial distribution and budget for submarine groundwater discharge in Eckernförde Bay (Western Baltic Sea). Limnol. Oceanogr. 49 (1), 157-167. doi:10.4319/lo.2004.49.1.0157

Schofield, O., Glenn, S., Bissett, P. W., Frazer, T. K., Iglesias-Rodriguez, D., and Moline, M. A. (2003). Development of regional coastal ocean observatories and the potential benefits to marine sanctuaries. Mar. Technol. Soc. J 37 (1), 54-67. doi:10.4031/002533203787537456

Schubert, M., Petermann, E., Stollberg, R., Gebel, M., Scholten, J., Knöller, K., et al. (2019). Improved approach for the investigation of submarine groundwater discharge by means of radon mapping and radon mass balancing. Water 11 (4), 749. doi: $10.3390 /$ w11040749

Schubert, M., Scholten, J., Schmidt, A., Comanducci, J., Pham, M., Mallast, U., et al. (2014). Submarine groundwater discharge at a single spot location: evaluation of different detection approaches. Water 6 (3), 584-601. doi:10. 3390/w6030584

Schutte, C. A., Wilson, A. M., Evans, T., Moore, W. S., and Joye, S. B. (2016). Methanotrophy controls groundwater methane export from a barrier island. Geochim. Cosmochim. Acta 179, 242-256. doi:10.1016/j.gca.2016.01.022

Seibert, S. L., Greskowiak, J., Prommer, H., Böttcher, M. E., and Massmann, G. (2019). Modeling of biogeochemical processes in a barrier island freshwater lens (Spiekeroog, Germany). J. Hydrol. 575, 1133-1144. doi:10.1016/j.jhydrol.2019. 05.094

Seidel, M., Beck, M., Greskowiak, J., Riedel, T., Waska, H., Suryaputra, I. N. A., et al. (2015). Benthic-pelagic coupling of nutrients and dissolved organic matter composition in an intertidal sandy beach. Mar. Chem. 176, 150-163. doi:10. 1016/j.marchem.2015.08.011

Shaban, A., Khawlie, M., Abdallah, C., and Faour, G. (2005). Geologic controls of submarine groundwater discharge: application of remote sensing to north Lebanon. Environ. Geol. 47 (4), 512-522. doi:10.1007/s00254-004-1172-3

Sharp, Z. D., Wostbrock, J. A. G., and Pack, A. (2018). Mass-dependent triple oxygen isotope variations in terrestrial materials. Geochem. Persp. Let. 7, 27-31. doi:10.7185/geochemlet.1815

Shum, K. T., and Sundby, B. (1996). Organic matter processing in continental shelf sediments - The subtidal pump revisited. Mar. Chem. 53 (1, 2), 81-87. doi:10. 1016/0304-4203(96)00014-x

Siemon, B., Auken, E., and Christiansen, A. V. (2009). Laterally constrained inversion of helicopter-borne frequency-domain electromagnetic data. J. Appl. Geophys. 67 (3), 259-268. doi:10.1016/j.jappgeo.2007.11.003

Siemon, B., Costabel, S., Voss, W., Meyer, U., Deus, N., Elbracht, J., et al. (2015). Airborne and ground geophysical mapping of coastal clays in Eastern Friesland, Germany. Geophysics 80 (3), Wb21-Wb34. doi:10.1190/geo2014-0102.1 
Siemon, B., Ibs-von Seht, M., Steuer, A., Deus, N., and Wiederhold, H. (2020). Airborne Electromagnetic, Magnetic, and Radiometric Surveys at the German North Sea Coast Applied to Groundwater and Soil Investigations. Remote Sensing 12 (10). doi:10.3390/rs12101629

Siemon, B., van Baaren, E., Dabekaussen, W., Delsman, J., Dubelaar, W., Karaoulis, M., et al. (2019). Automatic identification of fresh-saline groundwater interfaces from airborne electromagnetic data in Zeeland, the The Netherlands. Near Surf. Geophys. 17 (1), 3-25.

Siermann, J., Harvey, C., Morgan, G., and Heege, T. (2014). Satellite derived bathymetry and digital elevation models (DEM), international petroleum technology conference. Qatar: International Petroleum Technology ConferenceDoha, 10.

Sippo, J. Z., Maher, D. T., Tait, D. R., Holloway, C., and Santos, I. R. (2016). Are mangroves drivers or buffers of coastal acidification? Insights from alkalinity and dissolved inorganic carbon export estimates across a latitudinal transect. Glob. Biogeochem. Cycles 30 (5), 753-766. doi:10. 1002/2015gb005324

Sirois, M., Couturier, M., Barber, A., Gélinas, Y., and Chaillou, G. (2018). Interactions between iron and organic carbon in a sandy beach subterranean estuary. Mar. Chem. 202, 86-96. doi:10.1016/j.marchem.2018. 02.004

Slomp, C. P., and Van Cappellen, P. (2004). Nutrient inputs to the coastal ocean through submarine groundwater discharge: controls and potential impact. J. Hydrol. 295 (1-4), 64-86. doi:10.1016/j.jhydrol.2004.02.018

Spiteri, C., Cappellen, P. V., and Regnier, P. (2008a). Surface complexation effects on phosphate adsorption to ferric iron oxyhydroxides along $\mathrm{pH}$ and salinity gradients in estuaries and coastal aquifers. Geochim. Cosmochim. Acta 72 (14), 3431-3445. doi:10.1016/j.gca.2008.05.003

Spiteri, C., Regnier, P., Slomp, C. P., and Charette, M. A. (2006). pH-Dependent iron oxide precipitation in a subterranean estuary. J. Geochem. Explorat. 88 (1-3), 399-403. doi:10.1016/j.gexplo.2005.08.084

Spiteri, C., Slomp, C. P., Charette, M. A., Tuncay, K., and Meile, C. (2008b). Flow and nutrient dynamics in a subterranean estuary (Waquoit Bay, MA, USA): Field data and reactive transport modeling. Geochim. Cosmochim. Acta 72 (14), 3398-3412. doi:10.1016/j.gca.2008.04.027

Spiteri, C., Slomp, C. P., Tuncay, K., and Meile, C. (2008c). Modeling biogeochemical processes in subterranean estuaries: Effect of flow dynamics and redox conditions on submarine groundwater discharge of nutrients. Water Resour. Res. 44 (2), 18. doi:10.1029/2007wr006071

Steuer, A., Siemon, B., and Auken, E. (2009). A comparison of helicopter-borne electromagnetics in frequency- and time-domain at the Cuxhaven valley in Northern Germany. J. Appl. Geophys. 67 (3), 194-205. doi:10.1016/j.jappgeo. 2007.07.001

Stieglitz, T. C., Cook, P. G., and Burnett, W. C. (2010). Inferring coastal processes from regional-scale mapping of 222Radon and salinity: examples from the Great Barrier Reef, Australia. J. Environ. Radioact 101 (7), 544-552. doi:10. 1016/j.jenvrad.2009.11.012

Stieglitz, T. (2005). Submarine groundwater discharge into the near-shore zone of the Great Barrier Reef, Australia. Mar. Pollut. Bull. 51 (1-4), 51-59. doi:10. 1016/j.marpolbul.2004.10.055

Straume, E. O., Gaina, C., Medvedev, S., Hochmuth, K., Gohl, K., Whittaker, J. M., et al. (2019). GlobSed: Updated Total Sediment Thickness in the World's Oceans. Geochem. Geophys. Geosyst. 20 (4), 1756-1772. doi:10.1029/ $2018 \mathrm{gc008115}$

Sugimoto, R., Kitagawa, K., Nishi, S., Honda, H., Yamada, M., Kobayashi, S., et al. (2017). Phytoplankton primary productivity around submarine groundwater discharge in nearshore coasts. Mar. Ecol. Prog. Ser. 563, 25-33. doi:10.3354/ meps11980

Sültenfuss, J., Roether, W., and Rhein, M. (2009). The Bremen mass spectrometric facility for the measurement of helium isotopes, neon, and tritium in water. Isotopes Environ. Health Stud. 45 (2), 83-95.

Sutter, E., and Ingham, M. (2017). Seasonal saline intrusion monitoring of a shallow coastal aquifer using time-lapse DC resistivity traversing. Near Surf. Geophys. 15 (1), 59-73. doi:10.3997/1873-0604.2016039

Suzumura, M., Ueda, S., and Sumi, E. (2000). Control of phosphate concentration through adsorption and desorption processes in groundwater and seawater mixing at sandy beaches in Tokyo Bay, Japan. J. Oceanogr. 56 (6), 667-673. doi:10.1023/a:1011125700301
Swarzenski, P. W., Burnett, W. C., Greenwood, W. J., Herut, B., Peterson, R., Dimova, N., et al. (2006). Combined time-series resistivity and geochemical tracer techniques to examine submarine groundwater discharge at Dor Beach, Israel. Geophys. Res. Lett. 33 (24), 6. doi:10.1029/2006gl028282

Szymczycha, B., Vogler, S., and Pempkowiak, J. (2012). Nutrient fluxes via submarine groundwater discharge to the Bay of Puck, southern Baltic Sea. Sci. Total Environ. 438, 86-93. doi:10.1016/j.scitotenv.2012.08.058

Tamborski, J. J., Cochran, J. K., and Bokuniewicz, H. J. (2017). Application of $224 \mathrm{Ra}$ and $222 \mathrm{Rn}$ for evaluating seawater residence times in a tidal subterranean estuary. Mar. Chem. 189, 32-45. doi:10.1016/j.marchem.2016. 12.006

Tamborski, J. J., Rogers, A. D., Bokuniewicz, H. J., Cochran, J. K., and Young, C. R. (2015). Identification and quantification of diffuse fresh submarine groundwater discharge via airborne thermal infrared remote sensing. Remote Sensing Environ. 171, 202-217. doi:10.1016/j.rse.2015.10.010

Taniguchi, M., Burnett, W. C., Cable, J. E., and Turner, J. V. (2002). Investigation of submarine groundwater discharge. Hydrol. Process 16 (11), 2115-2129. doi:10. 1002/hyp.1145

Taniguchi, M., Dulai, H., Burnett, K. M., Santos, I. R., Sugimoto, R., Stieglitz, T., et al. (2019). Submarine Groundwater Discharge: Updates on Its Measurement Techniques, Geophysical Drivers, Magnitudes, and Effects. Front. Environ. Sci. 7 (14), 141. doi:10.3389/fenvs.2019.00141

Tao, Y., Deng, Y., Du, Y., Xu, Y., Leng, Z., Ma, T., et al. (2020). Sources and enrichment of phosphorus in groundwater of the Central Yangtze River Basin. Sci. Total Environ. 737, 139837. doi:10.1016/j.scitotenv.2020.139837

Teubner, P. P., Breier, R., Coppola, L., Groening, M., Jeandel, C., Jull, A. J. T., et al. (2011). Tracing of water masses using a multi isotope approach in the southern Indian Ocean. Earth Planet. Sci. Lett. 302 (1-2), 14-26. doi:10.1016/j.epsl.2010. 11.026

Tholen, C., Nolle, L., and Werner, J. (2019). “On the Influence of Localisation and Communication Error on the Behaviour of a Swarm of Autonomous Underwater Vehicles", in Recent advances in soft computing. Cham: Springer International Publishing, 68-79.

Tiedje, J. M. (1988). Ecology of denitrification and dissimilatory nitrate reduction to ammonium. Biol. anaerobic Microorg. 717, 179-244.

Tolstikhin, I. N., and Kamenskii, I. L. (1969). Determination of groundwater age by the T- 3He method. Geochem. Int. 6, 810-811.

Tréguer, P. J., and De La Rocha, C. L. (2013). The World Ocean Silica Cycle. Annu. Rev. Mar. Sci. 5 (1), 477-501. doi:10.1146/annurev-marine-121211-172346

Tyler, R. H., Boyer, T. P., Minami, T., Zweng, M. M., and Reagan, J. R. (2017). Electrical conductivity of the global ocean. Earth Planets Space 69 (1), 156. doi:10.1186/s40623-017-0739-7

Uchiyama, Y., Nadaoka, K., Rölke, P., Adachi, K., and Yagi, H. (2000). Submarine groundwater discharge into the sea and associated nutrient transport in a sandy beach. Water Resour. Res. 36 (6), 1467-1479. doi:10.1029/2000wr900029

Ullman, W. J., Chang, B., Miller, D. C., and Madsen, J. A. (2003). Groundwater mixing, nutrient diagenesis, and discharges across a sandy beachface, Cape Henlopen, Delaware (USA). Estuarine, Coastal Shelf Sci. 57 (3), 539-552. doi:10.1016/s0272-7714(02)00398-0

Utsunomiya, T., Hata, M., Sugimoto, R., Honda, H., Kobayashi, S., Miyata, Y., et al. (2017). Higher species richness and abundance of fish and benthic invertebrates around submarine groundwater discharge in Obama Bay, Japan. J. Hydrol. Reg. Stud. 11, 139-146. doi:10.1016/j.ejrh.2015.11.012

Vahtmäe, E., Paavel, B., and Kutser, T. (2020). How much benthic information can be retrieved with hyperspectral sensor from the optically complex coastal waters?. J. Appl. Remote Sensing 14 (1), 016504. doi:10.1117/1.jrs.14. 016504

van der Grift, B., Rozemeijer, J. C., Griffioen, J., and van der Velde, Y. (2014). Iron oxidation kinetics and phosphate immobilization along the flow-path from groundwater into surface water. Hydrol. Earth Syst. Sci. 18, 4687-4702. doi:10. 5194/hess-18-4687-2014

Van Ryswyk, M. (2020). Planet announces $50 \mathrm{~cm}$ SkySat imagery, tasking dashboard and up to $12 x$ Available:https://www.planet.com/pulse/taskingdashboard-50cm-12x-revisit-announcement/.Revisit Planet News.

Vidon, P., Allan, C., Burns, D., Duval, T. P., Gurwick, N., Inamdar, S., et al. (2010). Hot Spots and Hot Moments in Riparian Zones: Potential for Improved Water Quality Management1. JAWRA J. Am. Water Resour. Assoc. 46 (2), 278-298. doi:10.1111/j.1752-1688.2010.00420.x 
Virtasalo, J. J., Schröder, J. F., Luoma, S., Majaniemi, J., Mursu, J., and Scholten, J. (2019). Submarine groundwater discharge site in the First Salpausselkä icemarginal formation, south Finland. Solid Earth 10 (2), 405-423. doi:10.5194/se10-405-2019

Wang, B., Zhang, X., Luan, Z., Chen, C. A., and Yan, J. (2018). Seabed domes with circular depressions in the North Yellow Sea. J. Ocean. Limnol. 36 (6), 2154-2165. doi:10.1007/s00343-019-7173-6

Wang, D., Lin, W., Yang, X., Zhai, W., Dai, M., and Arthur Chen, C.-T. (2012). Occurrences of dissolved trace metals $(\mathrm{Cu}, \mathrm{Cd}$, and $\mathrm{Mn})$ in the Pearl River Estuary (China), a large river-groundwater-estuary system. Continental Shelf Res. 50-51, 54-63. doi:10.1016/j.csr.2012.10.009

Wang, G., Jing, W., Wang, S., Xu, Y., Wang, Z., Zhang, Z., et al. (2014). Coastal Acidification Induced by Tidal-Driven Submarine Groundwater Discharge in a Coastal Coral Reef System. Environ. Sci. Technol. 48 (22), 13069-13075. doi:10. $1021 /$ es5026867

Wang, G., Wang, Z., Zhai, W., Moore, W. S., Li, Q., Yan, X., et al. (2015). Net subterranean estuarine export fluxes of dissolved inorganic C, N, P, Si, and total alkalinity into the Jiulong River estuary, China. Geochimica Et Cosmochimica Acta 149, 103-114. doi:10.1016/j.gca.2014.11.001

Waska, H., Brumsack, H.-J., Massmann, G., Koschinsky, A., Schnetger, B., Simon, H., et al. (2019a). Inorganic and organic iron and copper species of the subterranean estuary: Origins and fate. Geochim. Cosmochim. Acta 259, 211-232. doi:10.1016/j.gca.2019.06.004

Waska, H., Greskowiak, J., Ahrens, J., Beck, M., Ahmerkamp, S., Böning, P., et al. (2019b). Spatial and temporal patterns of pore water chemistry in the inter-tidal zone of a high energy beach. Front. Mar. Sci. 6 (154), 12. doi:10.3389/fmars.2019.00154

Waska, H., and Kim, G. (2010). Differences in microphytobenthos and macrofaunal abundances associated with groundwater discharge in the intertidal zone. Mar. Ecol. Prog. Ser. 407, 159-172. doi:10.3354/meps08568

Waska, H., and Kim, G. (2011). Submarine groundwater discharge (SGD) as a main nutrient source for benthic and water-column primary production in a large intertidal environment of the Yellow Sea. J. Sea Res. 65 (1), 103-113. doi:10.1016/j.seares.2010.08.001

Webb, J. R., Santos, I. R., Maher, D. T., Tait, D. R., Cyronak, T., Sadat-Noori, M., et al. (2019). Groundwater as a source of dissolved organic matter to coastal waters: Insights from radon and CDOM observations in 12 shallow coastal systems. Limnol. Oceanogr. 64 (1), 182-196. doi:10.1002/lno.11028

Webster, I. T., Hancock, G. J., and Murray, A. S. (1994). Use of Radium Isotopes to Examine Pore-Water Exchange in an Estuary. Limnol. Oceanogr. 39 (8), 1917-1927. doi:10.4319/lo.1994.39.8.1917

Weinstein, Y., Yechieli, Y., Shalem, Y., Burnett, W. C., Swarzenski, P. W., and Herut, B. (2011). What is the role of fresh groundwater and recirculated seawater in conveying nutrients to the Coastal Ocean? Environ. Sci. Technol. 45 (12), 5195-5200. doi:10.1021/es104394r

Weinstein, Y., Burnett, W. C., Swarzenski, P. W., Shalem, Y., Yechieli, Y., and Herut, B. (2007). Role of aquifer heterogeneity in fresh groundwater discharge and seawater recycling: An example from the Carmel coast, Israel. J. Geophys. Res.-Oceans 112 (C12), 12. doi:10.1029/2007jc004112

Welti, N., Gale, D., Hayes, M., Kumar, A., Gasparon, M., Gibbes, B., et al. (2015). Intertidal diatom communities reflect patchiness in groundwater discharge. Estuarine, Coastal Shelf Sci. 163, 116-124.doi:10.1016/j.ecss.2015.06.006

Weschenfelder, J., Klein, A. H. F., Green, A. N., Aliotta, S., de Mahiques, M. M., Ayres Neto, A., et al. (2016). The control of palaeo-topography in the preservation of shallow gas accumulation: Examples from Brazil, Argentina and South Africa. Estuarine Coastal Shelf Sci. 172, 93-107. doi:10.1016/j.ecss.2016.02.005

Whiticar, M. J. (2002). Diagenetic relationships of methanogenesis, nutrients, acoustic turbidity, pockmarks and freshwater seepages in Eckernforde Bay. Mar. Geol. 182 (1, 2), 29-53. doi:10.1016/s0025-3227(01)00227-4

Whiticar, M. J., and Werner, F. (1981). Pockmarks: Submarine vents of natural gas or freshwater seeps?. Geo-Marine Lett. 1 (3), 193-199. doi:10.1007/bf02462433

Wigley, T. M. L., Plummer, L. N., and Pearson, F. J. (1978). Mass transfer and carbon isotope evolution in natural water systems. Geochim. Cosmochim. Acta 42 (8), 1117-1139. doi:10.1016/0016-7037(78)90108-4
Wilford, J., Bierworth, P. N., and Pearson, M. A., C. (1997). Application of airborne gamma ray spectrometry in soil/regolith mapping. J. Aust. Geol. Geophys. 17, 201-216.

Wilson, J., and Rocha, C. (2012). Regional scale assessment of Submarine groundwater discharge in Ireland combining medium resolution satellite imagery and geochemical tracing techniques. Remote Sensing Environ. 119 (0), 21-34. doi:10.1016/j.rse.2011.11.018

Winde, V., Böttcher, M. E., Voss, M., and Mahler, A. (2017). Bladder wrack (Fucus vesiculosus) as a multi-isotope bio-monitor in an urbanized fjord of the western Baltic Sea. Isotopes Environ. Health Stud. 53 (6), 563-579. doi:10.1080/ 10256016.2017.1316980

Winde, V., Böttcher, M. E., Escher, P., Böning, P., Beck, M., Liebezeit, G., et al. (2014). Tidal and spatial variations of $\mathrm{DI}^{13} \mathrm{C}$ and aquatic chemistry in a temperate tidal basin during winter time. J. Mar. Syst. 129, 396-404. doi:10. 1016/j.jmarsys.2013.08.005

Wolanski, E., (2007). Estuarine ecohydrology. Amsterdam; Oxford, Elsevier, xi, 157.

Wong, W. W., Applegate, A., Poh, S. C., and Cook, P. L. M. (2020). Biogeochemical attenuation of nitrate in a sandy subterranean estuary: insights from two stable isotope approaches. Limnol Oceanogr 65 (12), 3098-3113. doi:10.1002/lno. 11576

Wunderlich, T., Fischer, P., Wilken, D., Hadler, H., Erkul, E., Mecking, R., et al. (2018). Constraining electric resistivity tomography by direct push electric conductivity logs and vibracores: an exemplary study of the Fiume Morto silted riverbed (Ostia Antica, western Italy). Geophysics 83 (3), B87-B103. doi:10. 1190/geo2016-0660.1

Xing, Q., Braga, F., Tosi, L., Lou, M., Zaggia, L., Teatini, P., et al. (2016). Detection of low salinity groundwater seeping into the Eastern Laizhou Bay (China) with the aid of landsat thermal data. J. Coastal Res. 74, 149-156. doi:10.2112/si74014.1

Yang, L., Chen, C.-T. A., Hong, H., Chang, Y.-C., and Lui, H.-K. (2015). Mixing behavior and bioavailability of dissolved organic matter in two contrasting subterranean estuaries as revealed by fluorescence spectroscopy and parallel factor analysis. Estuarine Coastal Shelf Sci. 166, 161-169. doi:10.1016/j.ecss. 2014.10.018

Zamrsky, D., Karssenberg, M. E., Cohen, K. M., Bierkens, M. F. P., and Oude Essink, G. H. P. (2020). Geological heterogeneity of coastal unconsolidated groundwater systems worldwide and its influence on offshore fresh groundwater occurrence. Front. Earth Sci. 7 (339). doi:10.3389/feart.2019. 00339

Zhang, Y.-C., Slomp, C. P., Broers, H. P., Bostick, B., Passier, H. F., Böttcher, M. E., et al. (2012). Isotopic and microbiological signatures of pyrite-driven denitrification in a sandy aquifer. Chem. Geol. 300-301, 123-132. doi:10. 1016/j.chemgeo.2012.01.024

Zhou, Y., Sawyer, A. H., David, C. H., and Famiglietti, J. S. (2019). Fresh submarine groundwater discharge to the near-global coast. Geophys. Res. Lett. 46, 5855-5863. doi:10.1029/2019gl082749

Zipperle, A., and Reise, K. (2005). Freshwater springs on intertidal sand flats cause a switch in dominance among polychaete worms. J. Sea Res. 54 (2), 143-150. doi:10.1016/j.seares.2005.01.003

Conflict of Interest: The authors declare that the research was conducted in the absence of any commercial or financial relationships that could be construed as a potential conflict of interest.

Copyright (c) 2021 Moosdorf, Böttcher, Adyasari, Erkul, Gilfedder, Greskowiak, Jenner, Kotwicki, Massmann, Müller-Petke, Oehler, Post, Prien, Scholten, Siemon, Ehlert von Ahn, Walther, Waska, Wunderlich and Mallast. This is an open-access article distributed under the terms of the Creative Commons Attribution License (CC $B Y$ ). The use, distribution or reproduction in other forums is permitted, provided the original author(s) and the copyright owner(s) are credited and that the original publication in this journal is cited, in accordance with accepted academic practice. No use, distribution or reproduction is permitted which does not comply with these terms. 